\title{
The Remarkable Antioxidant and Anti-Inflammatory Potential of the Extracts of the Brown Alga Cystoseira amentacea var. stricta
}

\author{
Gina De La Fuente ${ }^{1}{ }^{\mathbb{D}}$, Marco Fontana ${ }^{1}$, Valentina Asnaghi ${ }^{1}$, Mariachiara Chiantore ${ }^{1}$, Serena Mirata ${ }^{1}$, \\ Annalisa Salis ${ }^{2}$ D, Gianluca Damonte ${ }^{2}$ (D) and Sonia Scarfi ${ }^{1,3, * \mathbb{D}}$
}

1 Department of Earth, Environment and Life Sciences (DISTAV), University of Genova, Via Pastore 3, 16132 Genova, Italy; gina.delafuente@edu.unige.it (G.D.L.F.); mapo_95@hotmail.it (M.F.); valentina.asnaghi@unige.it (V.A.); mariachiara.chiantore@unige.it (M.C.); serena.mirata@edu.unige.it (S.M.)

2 Centre of Excellence for Biomedical Research (CEBR), University of Genova, Viale Benedetto XV 9, 16132 Genova, Italy; annalisa.salis@unige.it (A.S.); gianluca.damonte@unige.it (G.D.)

3 Centro 3R, Interuniversitary Center for the Promotion of the Principles of the 3Rs in Teaching and Research, Via Caruso 16, 56122 Pisa, Italy

* Correspondence: soniascarfi@unige.it; Tel.: +39-010-3533-8227

Citation: De La Fuente, G.; Fontana, M.; Asnaghi, V.; Chiantore, M.; Mirata, S.; Salis, A.; Damonte, G.; Scarfi, S. The Remarkable Antioxidant and AntiInflammatory Potential of the Extracts of the Brown Alga Cystoseira amentacea var. stricta. Mar. Drugs 2021, 19, 2. https://dx.doi.org/10.3390/ md19010002

Received: 7 December 2020 Accepted: 17 December 2020 Published: 23 December 2020

Publisher's Note: MDPI stays neutral with regard to jurisdictional claims in published maps and institutional affiliations.

Copyright: () 2020 by the authors. Licensee MDPI, Basel, Switzerland. This article is an open access article distributed under the terms and conditions of the Creative Commons Attribution (CC BY) license (https: / / creativecommons.org / licenses/by/4.0/).

\begin{abstract}
Inflammation and oxidative stress are part of the complex biological responses of body tissues to harmful stimuli. In recent years, due to the increased understanding that oxidative stress is implicated in several diseases, pharmaceutical industries have invested in the research and development of new antioxidant compounds, especially from marine environment sources. Marine seaweeds have shown the presence of many bioactive secondary metabolites, with great potentialities from both the nutraceutical and the biomedical point of view. In this study, 50\%-ethanolic and DMSO extracts from the species C. amentacea var. stricta were obtained for the first time from seaweeds collected in the Ligurian Sea (north-western Mediterranean). The bioactive properties of these extracts were then investigated, in terms of quantification of specific antioxidant activities by relevant ROS scavenging spectrophotometric tests, and of anti-inflammatory properties in LPSstimulated macrophages by evaluation of inhibition of inflammatory cytokines and mediators. The data obtained in this study demonstrate a strong anti-inflammatory effect of both C. amentacea extracts (DMSO and ethanolic). The extracts showed a very low grade of toxicity on RAW 264.7 macrophages and L929 fibroblasts and a plethora of antioxidant and anti-inflammatory effects that were for the first time thoroughly investigated. The two extracts were able to scavenge $\mathrm{OH}$ and NO radicals (OH EC50 between 392 and $454 \mu \mathrm{g} / \mathrm{mL}$; NO EC50 between 546 and $1293 \mu \mathrm{g} / \mathrm{mL}$ ), to partially rescue $\mathrm{H}_{2} \mathrm{O}_{2}$-induced RAW 264.7 macrophages cell death, to abate intracellular ROS production in $\mathrm{H}_{2} \mathrm{O}_{2}$-stimulated macrophages and fibroblasts and to strongly inhibit LPS-induced inflammatory mediators, such as NO production and IL-1 $\alpha$, IL-6, cyclooxygenase- 2 and inducible NO synthase gene expression in RAW 264.7 macrophages. These results pave the way, for the future use of $C$. amentacea metabolites, as an example, as antioxidant food additives in antiaging formulations as well as in cosmetic lenitive lotions for inflamed and/or damaged skin.
\end{abstract}

Keywords: brown algae; Fucales; biological effects; gene expression

\section{Introduction}

Inflammation is part of the complex biological response of body tissues to harmful stimuli, such as pathogens, particulate matter, damaged cells, injury or toxic compounds. It develops as a protective response, involving cells of the immune system and a plethora of molecular mediators released by both immune cells and damaged tissues. The function of inflammation is in resolving the initial cause of cell injury, to clear out necrotic cells in the compromised tissues, and to set the right conditions for tissue repair. In some disorders a prolonged inflammation may develop, giving rise to chronic inflammatory diseases, 
due to the disruption of the molecular signals necessary to control the process which normally is self-limiting. [1]. Furthermore, chronic inflammation is nowadays a broadly recognized feature of aging and of age-related diseases such as diabetes, hypertension, atherosclerosis, and cancer [2]. In particular, the aging phenomenon shows a chronic lowgrade inflammation at the systemic level although in the absence of a recognised infection. This phenomenon has been defined as "inflammaging" and represents a significant risk factor for morbidity and mortality in the elderly.

Macrophages play an important role in the inflammatory response, both in acute and chronic inflammation. They act at numerous levels during the response by engulfing foreign agents, by eliminating apoptotic cells and tissue debris in the damaged area. Concomitantly, they release inflammatory mediators able to orchestrate the various phases of the process and the subsequent healing of the tissue. The vast arsenal of released molecules include chemokines, cytokines, growth factors and small second messengers such as nitric oxide $(\mathrm{NO})$ and prostaglandin $\mathrm{E}_{2}\left(\mathrm{PGE}_{2}\right)$ produced by overexpressed inducible $\mathrm{NO}$ synthase (iNOS), and cyclooxygenase 2 (COX-2) enzymes, respectively [3,4].

Among the cytokines released by activated macrophages, the tumour necrosis factor (TNF)- $\alpha$, interleukin-1 (IL-1), and interleukin-6 (IL-6) play a prominent role in the propagation and development of the inflammation, together with $\mathrm{NO}$ and $\mathrm{PGE}_{2}$, by recruiting inflammatory cells and by increasing vascular permeability [5]. The inflammatory response is beneficial if the abovementioned cytokines are produced in appropriate amounts, but it becomes detrimental when they are produced in a deregulated fashion. For instance, the overproduction of IL-1 $\beta$ and TNF promotes an acute systemic inflammatory response typical of multi-organ failure and of septic shock [6]. Therefore, the inhibition of these inflammatory mediators is considered an indispensable approach for the treatment of inflammatory diseases in general.

Inflammation can also be triggered and propagated by oxidative stress, which occurs when the body antioxidant defense system fails to contain the production and release of reactive oxygen species (ROS) [7]. ROS, such as hydrogen peroxide, superoxide, hydroxyl and NO radicals, are generated in many cellular redox processes also during the inflammatory response. The consequence of their overproduction is an uncontrolled reaction with other molecules, such as proteins, DNA and lipids [8], inducing oxidative damage to biomolecules. Therefore, ROS overproduction is detrimental to the body physiological homeostasis, and besides inflammation, it has been shown to participate in the pathogenesis of several human degenerative diseases, including cardiovascular and neurodegenerative disorders and cancer $[9,10]$.

In recent years, due to the numerous diseases in which the oxidative stress is implicated, a great deal of attention from the pharmaceutical industries has arisen for the research and development of new antioxidant compounds. These new compounds have been researched also, and with great success, in marine environment sources. This has allowed the development of new branches of the marine biotechnological research in the quest of natural and safe antioxidative agents from aquatic organisms to replace synthetic antioxidants, some of which have been restricted due to their carcinogenicity [11,12]. In particular, the marine seaweeds have shown the presence of many bioactive secondary metabolites, with great potentialities both from the nutraceutical, as well as from the biomedical point of view [13]. In the last twenty years this research allowed the identification of new antioxidant [14,15], anti-inflammatory [16,17] antimicrobial [15], and anti-tumoral drugs [18] found in red, green and brown macroalgae. Several studies have recognized brown algae as the most powerful source of natural antioxidants compared to green and red algae, mainly because of their remarkable content in polyphenols and phlorotannins [18-26]. Large brown algae belonging to the orders Laminariales and Fucales, thrive in the intertidal and subtidal rocky reefs worldwide providing food and refuge for many associated species, as well as controlling nutrient cycling and productivity of their habitats. Therefore, they play a relevant ecological role as foundation species, enhancing habitat complexity, biodiversity and ecosystem functions of rocky coasts [27,28]. 
These species have shown very high antioxidant activity [25]. In the Mediterranean Sea the most important foundation species belong to the widespread genus of Cystoseira sensu lato (Fucales order), which holds very promising features in terms of secondary metabolites production [29-33]. In fact, many interesting molecules such as terpenoids, alkaloids and steroids have been isolated from different species of the genus, but few studies on the pharmacological properties of these compounds have been published [34-43].

In this study, the properties of 50\%-ethanolic and DMSO extracts from the species C. amentacea var. stricta Montagne (hereafter C. amentacea) were thoroughly investigated for the first time in seaweeds collected in the Ligurian Sea (north-western Mediterranean). Since in the literature there is poor knowledge on the molecular targets of the compounds contained in C. amentacea extracts, the bioactive properties of these extracts were assessed in terms of quantification of specific antioxidant activities by opportune ROS scavenging tests, identifying the main oxidant targets of the extracts inside the cells and the anti-inflammatory properties in LPS-stimulated macrophages by evaluating the specific abatement of dangerous inflammatory cytokines and mediators by molecular studies. Contextually, cytotoxicity was also assessed in order to investigate the possible use of these extracts as nutraceuticals, cosmeceuticals or anti-inflammatory drugs in human health issues.

\section{Results and Discussion}

2.1. Extraction Yield, Total Phenolic and Flavonoid Content of C. amentacea Extracts

The 50\%-ethanol and DMSO extractions used to retrieve a more hydrophilic and a more hydrophobic fraction, respectively, were performed in mild conditions (stirring at $30^{\circ} \mathrm{C}$ for $48 \mathrm{~h}$, in the dark) resulting in a yield of $310 \pm 50$ and $171 \pm 32 \mathrm{mg}$ of crude extract per gram of dried algae, respectively. These gentle conditions were chosen with the aim of recovering molecular products with the maximal stability, since it has been reported [40] that some degree of thermal instability (15-30\% depending on the molecular species) is observed for polyphenols at temperatures higher than $60^{\circ} \mathrm{C}$, as well as a certain degree of photo-oxidation by UV-light exposure (10-50\%). These yields were comparable to the yields obtained by various extraction solvents used to assess the bioactive potential of $C$. barbata by Trifan et al. [41], and significantly higher than those obtained by Ruberto et al. [36] by $\mathrm{CH}_{2} \mathrm{Cl}_{2}$ organic extraction of various species from the genus Cystoseira (from $2.1 \%$ to $6.7 \%$ depending on the species). In particular, the ethanolic extract in our study (31\% yield) was comparable to the $70 \%$-acetone extract for C. barbata by Trifan et al. (24\% yield) [41], although in our case it was obtained by using a cheaper and less toxic solvent. A great contributing factor to the antioxidant and anti-inflammatory activity of numerous plant extracts is due to their content in polyphenols. Therefore, we initially measured the total phenolic content (TPC) and the total flavonoid content (TFC) of the two extracts by the appropriate colorimetric assays. The results, expressed as $\mu \mathrm{g}$ of TPC/TFC per mg of crude extract, are displayed in Table 1. Both extracts contained measurable quantities of TPC and TFC, although in different proportions. The ethanolic extract in fact, contained $20.3 \mu \mathrm{g}$ $\mathrm{TPC} / \mathrm{mg}$ crude extract (corresponding to $6.3 \mathrm{mg} / \mathrm{g}$ dried algae) of which the $15.3 \%$ was constituted by flavonoids, while in the DMSO extract the TPC content was $65.9 \mu \mathrm{g} / \mathrm{mg}$ crude extract (corresponding to $11.2 \mathrm{mg} / \mathrm{g}$ dried algae) of which the $24 \%$ was represented by flavonoids. Both quantifications underlined a higher content of polyphenols as well as of flavonoids in the DMSO extract with respect to the $50 \%$-ethanol extract. In particular, the TPC and TFC contents of the DMSO extract were 3.2 and 5.1 folds higher than the ethanolic extract, respectively. These results are very similar to the TPC observed in the single other study on C. amentacea collected from the Mediterranean Sicilian coastal area evaluating the seasonal fluctuation of TPC in this seaweed [37]. In that case, extraction of polyphenols was obtained with $95 \%$ ethanol and the TPC displayed a seasonal fluctuation from a minimum TPC content in winter (less than $1 \mathrm{mg} / \mathrm{g}$ dried algae) to a maximum content in summer ( $6 \mathrm{mg} / \mathrm{g}$ dried algae). Since the algae used in our study were collected in the summer season in the Mediterranean from the Ligurian coasts, our data confirm the data from the 
Sicilian study. Furthermore, the results of the two studies indicate that there is no difference in terms of TPC yield between the two extraction methods (50\%-ethanol or 95\%-ethanol), although the conditions used in our study are more attractive both for their safety (less solvent flammability) and their convenience (cheaper solution). Comparable to the values obtained in C. amentacea from the Mediterranean Sea, were also the TPC values obtained from Kosanic et al. [38] from the same species collected in the Adriatic Sea and acetoneextracted, which phenolic content was of $81 \mu \mathrm{g} / \mathrm{mg}$ extract. Other studies report TPC yields from extracts of various species of the Cystoseira genus, displaying a large variability: $50-61 \mathrm{mg} / \mathrm{g}$ dried weight in the aqueous extracts from C. compressa, C. crinita and C. sedoides (Mediterranean Tunisian coastal areas) in Mhadhebi et al. [34], 126-236 mg/g dried weight in the acetone, methanol and water extracts from C. barbata (Black Sea coastal areas) in Trifan et al. [41], 4.7-32 mg/g dried weight from C. humilis; 45-165 mg/g dried weight from C. tamariscifolia and 17-127 mg/g dried weight from C. usneoides (Portuguese coasts) in organic sequential extracts, in Vizetto-Duarte et al. [39]. Comparing C. amentacea TPC content to the other Cystoseira species analysed in the literature we can infer that this species seems in general to a have a lower content in TPC compared to the others ( 1 order of magnitude), with similar yields obtained only in C. humilis from the Portuguese coasts. This is probably not only due to the different approach applied in the various studies, i.e., extraction conditions and seasonality, but also to other factors related to the variability of the habitats of each species, such as irradiance, temperature and bathymetric level.

Table 1. TPC and TFC of C. amentacea extracts.

\begin{tabular}{ccc}
\hline Type of Extract & TPC $(\boldsymbol{\mu g} / \mathbf{m g}$ Crude Extract) & TFC $(\mu \mathrm{g} / \mathbf{m g}$ Crude Extract) \\
\hline $50 \%$-ethanol & $20.3 \pm 0.74$ & $3.1 \pm 0.48$ \\
\hline DMSO & $65.9 \pm 1.74$ & $15.8 \pm 0.51$ \\
\hline
\end{tabular}

Quantification of the total phenolic content (TPC) and of the total flavonoid content (TFC) by the Folin-Ciocalteu and by the $\mathrm{AlCl}_{3}$ colorimetric assays, respectively in the two extracts obtained by C. amentacea. Values are expressed as mean \pm S.D.

\subsection{HPLC-MS Analysis}

The HPLC-MS/MS analysis was performed with the aim of identifying the main molecular components present in the extracts. The analysis of the two extracts showed the same molecular species in both samples and mainly pointed out the presence of meroditerpene-like structures previously described in the same genus [26,29-32]. In Figure 1 the tandem MS analyses of the 50\%-ethanol extract (panel A) and of the DMSO extract (panel B) are shown. The figure shows for both extracts the Total Ion Chromatogram (TIC, chromatogram $\mathrm{A}$ in both panels), and then the fragmentation patterns of four different meroditerpene molecules found in both extracts (in both panels, chromatograms B, C, $\mathrm{D}$ and $\mathrm{E})$. These are ascribable to structures containing the chroman or quinone groups as: cystoketal quinone (chromatogram B in both extract), demethylcystoketal chromane (chromatogram C in both extracts) and cystoketal chromane, and/or cystoketal (chromatogram $\mathrm{D}$ in both extracts) highlighted in the figure as extracted ion chromatograms of respectively, 423.3 (B) and 425.3 (C) and 439.3 (D) mass/charge ratios. Figure 2 shows the tandem mass fragmentation spectra (panels I, II, III and IV) of the ions extracted in Figure 1 (chromatograms B, C, D and E, respectively in both extracts) confirming the structure of the molecules. 
A 50\%_ETHANOL

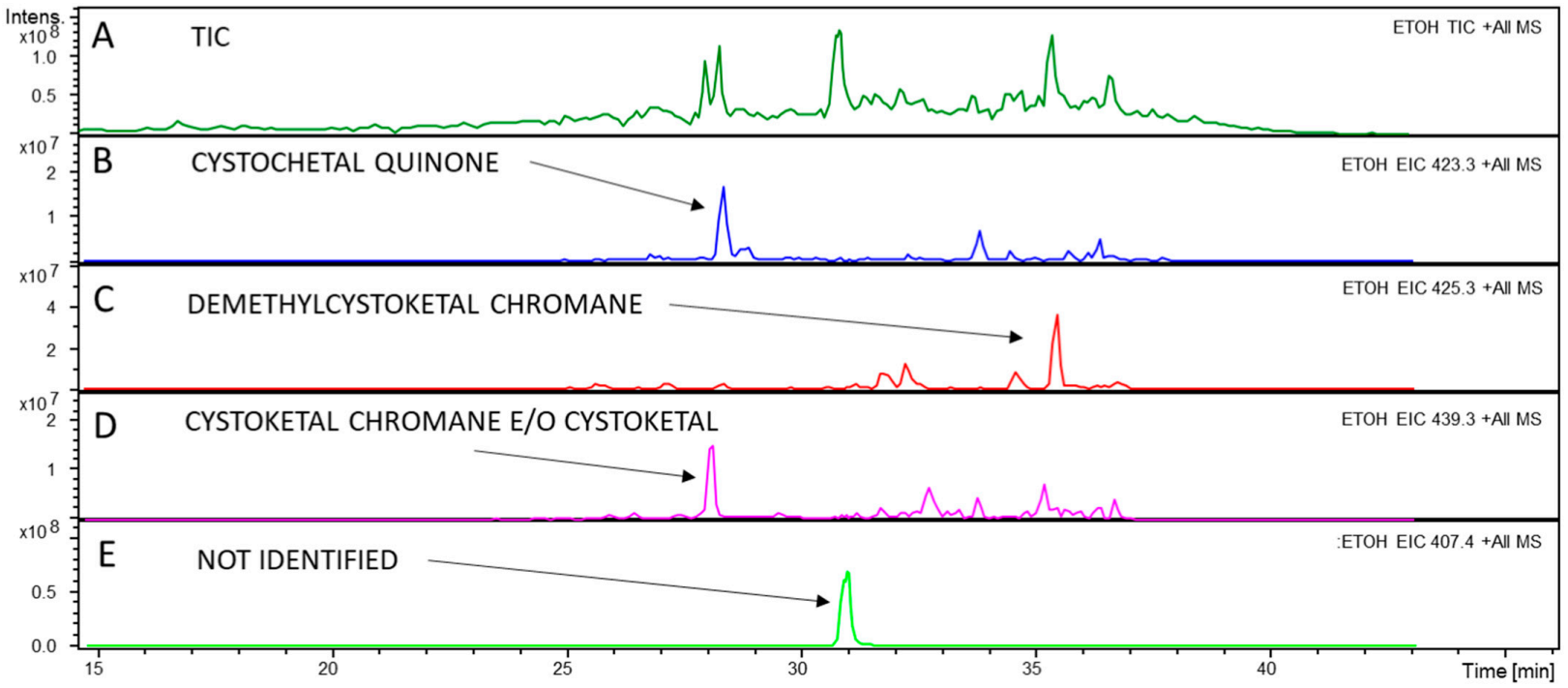

B

DMSO

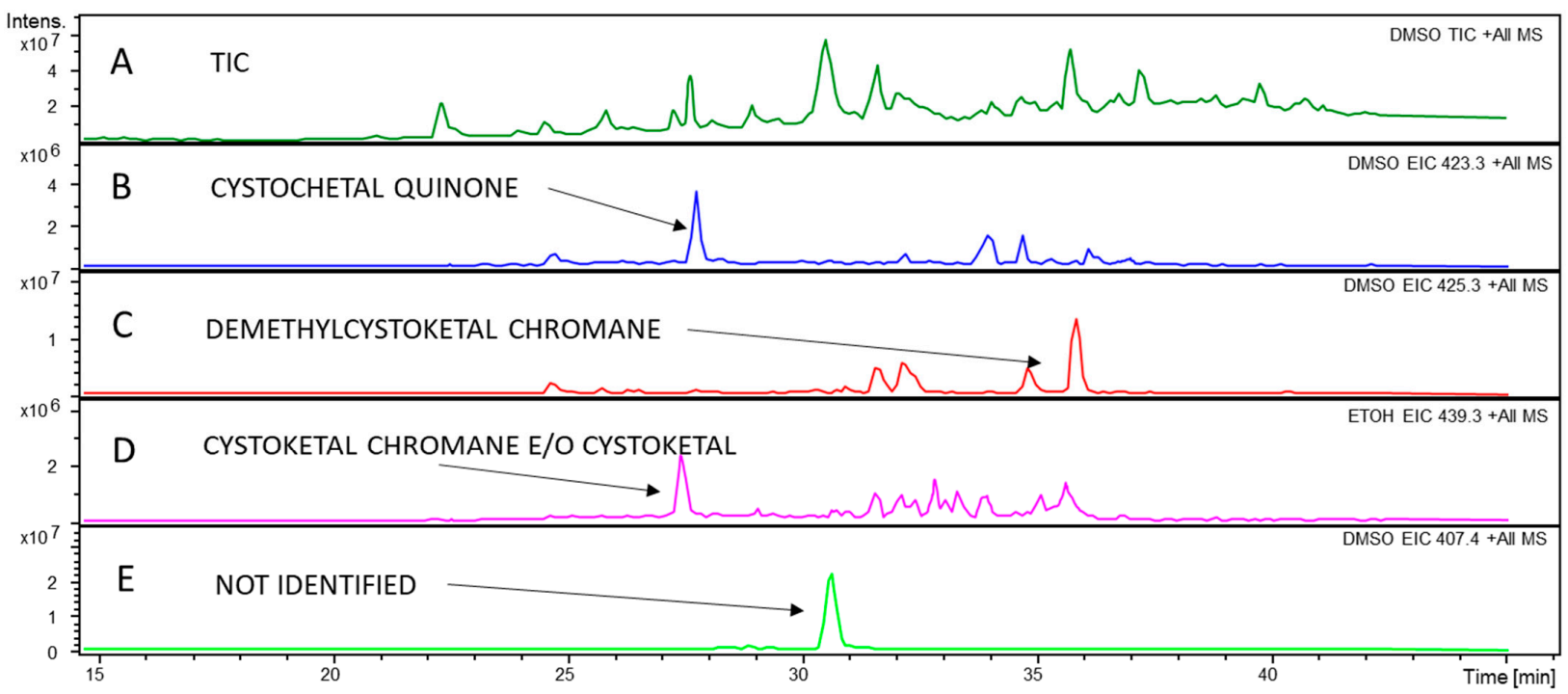

Figure 1. Total ion current (TIC) and Extracted ion chromatograms obtained by full scan MS/MS analysis coupled to HPLC separation of an aliquot of the C. amentacea 50\% ethanol extract in panel (A) and DMSO extract in panel (B) (starting dilution $5 \mathrm{mg} / \mathrm{mL}$ ), acquiring the most abundant species under each peak. Chromatogram A in both panels represent the TIC of each extract while chromatograms B, C, D and E in both panels represent the extracted ion chromatograms of 423.3 (B), 425.3 (C) 439.3 (D), and 407.4 (E) mass/charge ratios. Acquisition was performed on negative and positive ions in the 100-1000 mass range and analyzed using the integrated software. 


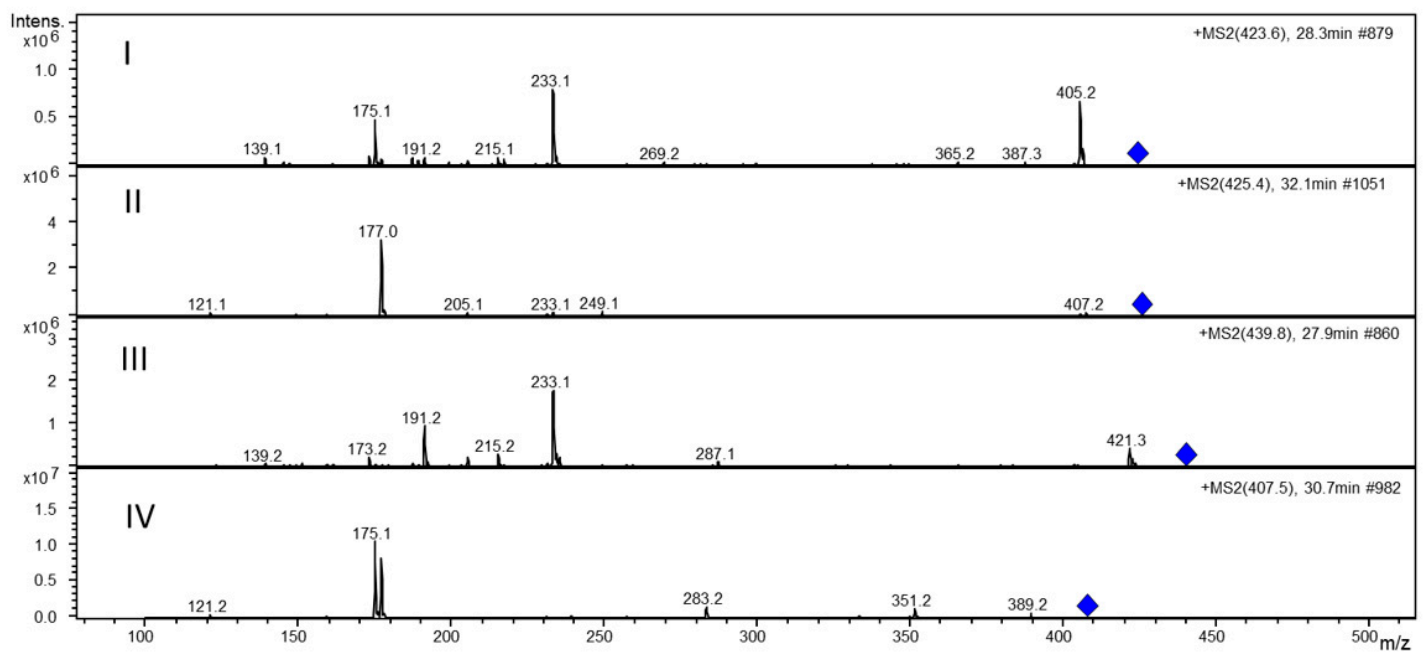

Figure 2. Tandem mass fragmentation spectra of extracted ions (blue diamonds) reported in Figure 1 (see chromatograms B, C, D and E, respectively, of both panels) of 423.3 (panel I), 425.3 (panel II), 439.3 (panel III) and 407.4 (panel IV) mass/charge ratios obtained by full scan MS/MS analysis coupled to HPLC and performed as reported in Figure 1.

Another unidentified signal at $m / z 407.4$ (Figure 1, chromatogram $\mathrm{E}$ in both extracts) is also present. In Figure 2, panel IV, the relative tandem mass spectrum is reported, where the simultaneous presence of the 175 and 177 fragments is attributable to both the chroman and the quinone reduced form (hydroquinone). In fact, the $m / z 175$ is consistent only with the quinone nucleus, while the $m / z$ at 177 is imputable to the presence of both the hydroquinone and the chroman group. Besides, the presence of the $m / z 191$ fragment is related to methyl derivatives of either these nuclei. In conclusion, the HPLC-MS analysis points out that both extracts seem to retrieve the same meroditerpene class of molecules from the algae, confirming the abundance of these bioactive compounds [26,32] in the Cystoseira amentacea Mediterranean seaweed. Therefore, the different efficacy of the two extracts in the various antioxidant and anti-inflammatory tests may be attributable to a quantitative, and not qualitative, difference of the molecules contained. This is also deductible from the TPC quantification reported in Table II, where, as already commented, the DMSO extract show a phenolic content almost three times higher than the $50 \%$-ethanol extract, which could explain the general better performance of the first one upon the second in the various tests performed in this study.

\subsection{Antioxidant Activity Evaluation of C. amentacea Extracts}

The antioxidant activity of the two extracts was evaluated by different methods investigating the overall radical scavenging activity and the Fe reducing power of $C$. amentacea metabolites, as well as the scavenging capacity of biologically dangerous radicals such as the highly reactive nitric oxide (NO) and hydroxyl radicals $(\mathrm{OH})$. The range of concentrations used for the assays was chosen to allow a comparison with previous works $[34-36,39,41-43]$. The overall radical scavenging activity measured by the DPPH assay revealed an elevated potential for both extracts (Figure 3A). At the highest concentration tested, in fact, both extracts showed a scavenging potential higher than $90 \%$, while at the lowest concentration the ethanolic extract retained a scavenging activity slightly higher than $50 \%$ (black bars), with a calculated $\mathrm{EC}_{50}$ of $205.1 \mu \mathrm{g} / \mathrm{mL}$, while at the same concentration the DMSO extract (white bars) showed a scavenging activity still higher than $80 \%$, with a calculated $\mathrm{EC}_{50}$ of $0.34 \mu \mathrm{g} / \mathrm{mL}$. Similar to our data, also the acetone extracts of C. amentacea var. spicata (Adriatic Sea, Montenegro coasts) from Stanojkovic et al. [35] showed a DPPH EC 50 of $150 \mu \mathrm{g} / \mathrm{mL}$ with an antioxidant activity close to the ethanolic extracts obtained in our study, indicating that the abundance of antioxidants metabolites produced by the same species (although a different variety) does not change considerably between the two marine environments (North-western Mediterranean and 
Adriatic). Conversely, although the TPC content is usually much lower than other species of the Cystoseira genus, C. amentacea var. stricta is considerably richer in antioxidant compounds or containing comparable amounts, depending on the species and on the extraction procedure. For example, Trifan et al. [41] reported a DPPH EC $\mathrm{E}_{50}$ of $C$. barbata extracts closely comparable to our study (from 88 to $211 \mu \mathrm{g} / \mathrm{mL}$ depending on the extraction solvent); Mhadhebi et al. [34] documented DPPH EC 50 values of 12,20 , and $75 \mu \mathrm{g} / \mathrm{mL}$ for C. compressa, C. crinita and C. sedoides extracts, respectively, while Vizetto-Duarte et al. [39] obtained significantly lower antioxidant potential from the organic extracts of $C$. humilis and C. usneoides (DPPH EC $\mathrm{E}_{50}>1 \mathrm{mg} / \mathrm{mL}$ ) compared to C. tamariscifolia extract (DPPH $\mathrm{EC}_{50}$ between 170 and $1080 \mu \mathrm{g} / \mathrm{mL}$ ). Particularly, the latter is the only one with values comparable to $C$. amentacea var. stricta extracts obtained in our study. Values comparable with our results were also obtained by Andrade et al. [42] for C. tamariscifolia and C. usneoides ethanolic extracts, while a very low antioxidant potential was found in $C$. nodicaulis and in C. spongiosus (DPPH EC $50>1 \mathrm{mg} / \mathrm{mL}$ ). Finally, Belattmania et al. [43] fractionation of fatty acids from C. humilis revealed a DPPH EC 50 of $580 \mu \mathrm{g} / \mathrm{mL}$, indicating that the antioxidant potential of the Cystoseira genus metabolites resides also in other promising classes of compounds besides the typical phenols.

\subsection{Scavenging Properties of $C$. amentacea Extracts}

After assessing the overall antioxidant activity of the extracts, the specific scavenging properties of particularly dangerous reactive oxygen species were analyzed in order to understand which of them would be intracellularly mostly affected by the pharmacological use of $C$. amentacea extracts, since usually, ROS are produced under oxidative stress as well as during acute and chronic inflammation.

The Fe-reducing power assay, was performed by the potassium ferricyanide method and is another measure of the antioxidant power of the extract, furthermore the ability to reduce Fe to the ferrous form can be also important in preventing the Fenton reaction, leading to the production of superoxide anion and may also facilitate the removal of hydroxyl radical by $\mathrm{Fe}(\mathrm{II})$ oxidation [44]. This assay revealed the presence of this chemical property in the two C. amentacea extracts (Figure 3B), showing significantly higher capacity to reduce the $\mathrm{Fe}$ (III) ion to $\mathrm{Fe}$ (II) in the DMSO extract (white bars) compared to the ethanolic extract (black bars). In particular, the results are expressed as percentage of the reducing activity of the two extracts at different concentrations compared to the reducing activity of a concentration of ascorbic acid that allows the complete Fe reduction $(20 \mu \mathrm{g} / \mathrm{mL}$, in our experimental conditions). The DMSO extract showed a reducing activity close to $90 \%$ at the highest concentration and higher than $60 \%$ at the lowest concentration $\left(\mathrm{EC}_{50} 113.9 \mu \mathrm{g} / \mathrm{mL}\right.$ ). Conversely, the highest concentration of the ethanolic extract exerted a reducing activity of $75 \%$, while at the lowest concentration the activity was less than $20 \%\left(\mathrm{EC}_{50} 643.5 \mathrm{\mu g} / \mathrm{mL}\right)$. The study of Mhadhebi et al. [34] is the only one that reports this specific assay on Cystoseira species extracts, particularly on $C$. compressa, $C$. crinita and $C$. sedoides whose values were 2.6, 0.9 and 0.7, respectively, expressed as $\mathrm{mg}$ of gallic acid equivalents (GAE)/g of dried alga. If we express our results on $C$. amentacea extracts as $\mathrm{mg}$ of ascorbic acid equivalents (AAE)/g of dried algae we obtain values of 2.5 and $3.7 \mathrm{mg} \mathrm{AAE} / \mathrm{g}$ dried algae, for ethanolic and DMSO extracts, respectively. Since it has been reported that gallic acid and ascorbic acid share very similar antioxidant activities [45] we can deduce that the performance of C. amentacea extracts in the Fe-reducing activity is comparable or higher respect to the activities reported in the literature for $C$. compressa, $C$. crinita and $C$. sedoides, holding very promising results. 

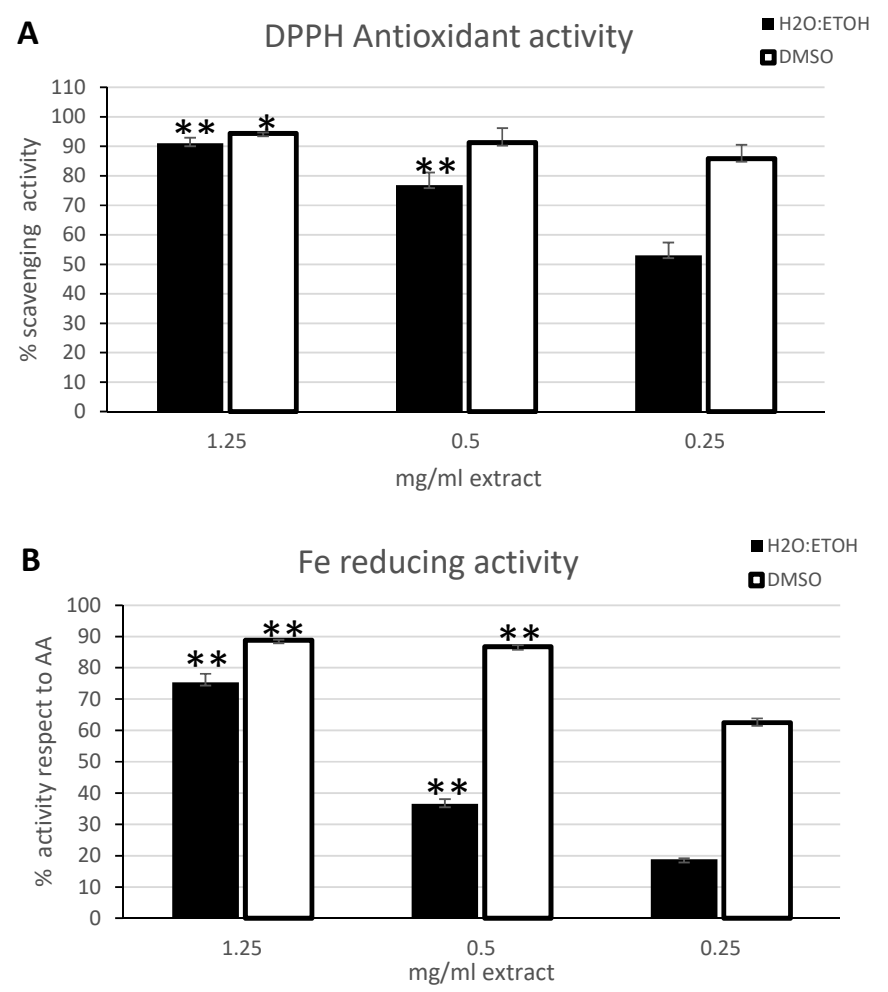

Figure 3. Activity and Fe reducing power of C. amentacea extracts in spectrophotometric tests. (A) ROS scavenging activity by the DPPH assay. Data are the mean \pm S.D. of three experiments performed in duplicate and are expressed as percentage of antioxidant activity respect to the absorbance of the negative control (calculated as specified in Section 4.7). Black bars: 50\%-ethanol extract, white bars: DMSO extract. Asterisks indicate significance in paired Tukey test between the various concentrations used (ANOVA $p<0.0005$, black bars: Tukey between 1.25 and 0.5 , between 1.25 and 0.25 , and between 0.5 and $0.25^{* *} p<0.001$; white bars: Tukey between 1.25 and 0.5 , and between 1.25 and $0.25{ }^{*} p<$ 0.005) (B) Fe (III) reducing power assay measured by the potassium ferricyanide method. Data are the mean \pm S.D. of three experiments performed in duplicate and are expressed as percentage of reducing power respect to the ascorbic acid positive control (calculated as specified in Section 4.8). Black bars: 50\%-ethanol extract, white bars: DMSO extract. Asterisks indicate significance in paired Tukey test between the various concentrations used (ANOVA $p<0.00001$, black bars: Tukey between 1.25 and 0.5 , between 1.25 and 0.25 , and between 0.5 and $0.25^{* *} p<0.0005$; white bars: Tukey between 1.25 and 0.5 , between 1.25 and 0.25 , and between 0.5 and $0.25^{* *} p<0.0005$ ).

$\mathrm{OH}$ and NO radicals are responsible for a broad molecular damage inside and outside the cells during oxidative stress and they are also involved as second messengers in key transduction pathways propagating the inflammatory signals [46]. Therefore, the specific scavenging capacity of the $C$. amentacea extracts towards the two radical species was tested by the respective spectrophotometric assays. The results demonstrate, in this case, that an elevated and selective scavenging potential of the ethanolic and DMSO extracts is detected (Figure 4). In particular, the $\mathrm{OH}$ radical scavenging activity was tested by the Mohr's salt assay showing a higher scavenging activity for the ethanolic extract compared to the DMSO extract (Figure 4A, black bars versus white, respectively) at the highest concentrations, with similar values at the lowest concentration tested. In fact, at the highest concentration the ethanolic extract exhibited a scavenging activity slightly above $70 \%$ while at the lowest concentration it was $42 \%\left(\mathrm{EC}_{50} 292.9 \mu \mathrm{g} / \mathrm{mL}\right)$. Conversely, the DMSO extract showed a scavenging activity of $54.5 \%$ at the highest concentration tested and of $48.7 \%$ at the lowest concentration ( $E_{50} 454.5 \mu \mathrm{g} / \mathrm{mL}$ ). The study of Andrade et al. [42] is, to our knowledge, the only one that reports of this assay on the Cystoseira genus, documenting EC25 values of hydroxyl radical scavenging below $500 \mu \mathrm{g} / \mathrm{mL}$, i.e., comparable to the 
C. amentacea values of our study, for the C. tamariscifolia species $(210 \mu \mathrm{g} / \mathrm{mL})$, while for the other species analyzed (C. usneoides, C. nodicaulis and C. spongiosus), a significantly poorer scavenging activity was shown. Thus, to date, we can assess that, according to literature, the C. amentacea extracts show the highest $\mathrm{OH}$ radical scavenging activity among the Cystoseira genus.
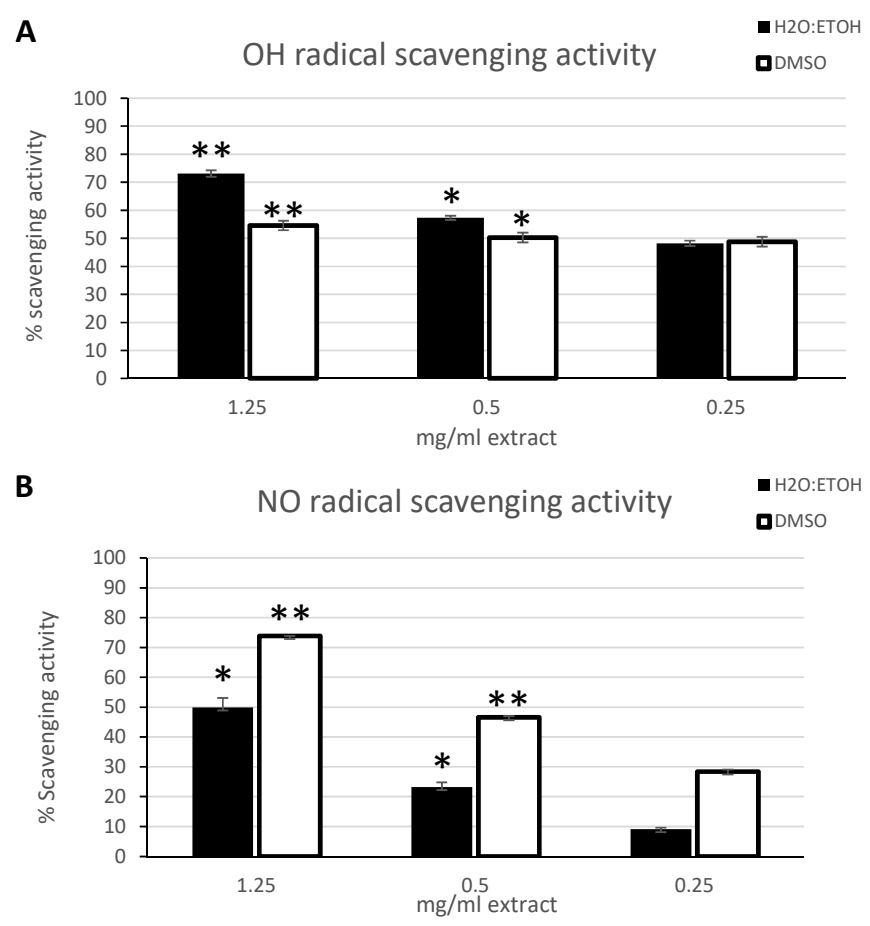

Figure 4. $\mathrm{OH}$ and $\mathrm{NO}$ radical scavenging activity of $\mathrm{C}$. amentacea extracts in spectrophotometric tests. (A) OH radical scavenging activity by the Mohr's salt assay. Data are the mean \pm S.D. of three experiments performed in duplicate and are expressed as percentage of antioxidant activity respect to the absorbance of the negative control (calculated as specified in Section 4.9). Black bars: 50\%-ethanol extract, white bars: DMSO extract. Asterisks indicate significance in paired Tukey test between the various concentrations used (ANOVA $p<0.001$, black bars: Tukey between 1.25 and 0.5 , between 1.25 and $0.25 * *<0.01$, between 0.5 and $0.25 * p<0.05$; white bars: Tukey between 1.25 and 0.5 , between 1.25 and $0.25, * * p<0.01$, between 0.5 and $0.25 * p<0.05)$ (B) NO radical scavenging activity measured by the sodium nitroprusside method coupled to the Griess assay. Data are the mean \pm S.D. of three experiments performed in duplicate and are expressed as percentage of antioxidant activity respect to the absorbance of the negative control (calculated as specified in Section 4.10). Black bars: 50\%-ethanol extract, white bars: DMSO extract. Asterisks indicate significance in paired Tukey test between the various concentrations used (ANOVA $p<0.0001$, black bars: Tukey between 1.25 and 0.5 , between 1.25 and 0.25 , and between 0.5 and $0.25 * p<0.001$, white bars: Tukey between 1.25 and 0.5 , between 1.25 and 0.25 , and between 0.5 and $0.25 * *<<0.0001$ ).

Finally, the NO scavenging activity of the extracts was evaluated by the nitroprusside $\mathrm{NO}$ donor assay. In this case, the DMSO extract showed a higher scavenging potential compared to the ethanolic extract (Figure $4 \mathrm{~B}$, white bars vs. black, respectively). In particular, the DMSO extract, at the highest concentration, showed a NO scavenging potential higher than $70 \%$, while at the lowest concentration it was slightly below $30 \%$ ( $\mathrm{EC}_{50}$ $546.2 \mu \mathrm{g} / \mathrm{mL}$ ). Instead, the ethanolic extract exhibited a scavenging activity of $49.9 \%$ and $9.1 \%$ at the highest and lowest concentration, respectively (EC50 $1293 \mu \mathrm{g} / \mathrm{mL}$ ). Compared to the only study of Andrade et al. [42] in literature, as abovementioned, the values obtained with $C$. amentacea in our study resulted, also in this case, similar to C. tamariscifolia $\left(\mathrm{EC}_{25}\right.$ of $240 \mu \mathrm{g} / \mathrm{mL}$ ) and C. nodicaulis $\left(\mathrm{EC}_{25} 480 \mu \mathrm{g} / \mathrm{mL}\right)$, but higher than C. usneoides $\left(\mathrm{EC}_{25}\right.$ $790 \mu \mathrm{g} / \mathrm{mL}$ ) and C. spongiosus $\left(\mathrm{EC}_{25} 3190 \mu \mathrm{g} / \mathrm{mL}\right)$. 
Overall, these data indicate that the antioxidant potential of C. amentacea var. stricta can be considered one of the most promising among the species of the Cystoseira genus with documented activity. This activity cannot be solely ascribed to the TPC and TFC content of the ethanolic and DMSO extracts because, as reported in the previous section, the TPC content in C. amentacea var. stricta extracts is, on the average, one order of magnitude lower than those measured in the other species of the Cystoseira genus. An important contributing factor to this notable antioxidant activity is likely due to the very rich variety and abundance of chemical products that have been identified in the various species of the genus, from terpenoids (meroditerpenes, linear diterpenes), also identified in our HPLC/MS analysis (Figures 1 and 2), to carbohydrates, lipids and vitamins to which the radical scavenging activity can also be ascribed [32]. Therefore, since for Cystoseira amentacea var. stricta few dated studies report of its phytochemical features [29-31,47,48], further studies could be performed, in order to have a clearer picture of the variety of compounds produced by this species.

\subsection{Cytotoxicity Test of C. amentacea Extracts}

The cytotoxicity of the two extracts at various concentrations was evaluated in two cell lines to investigate the possible use of these extracts as nutraceuticals or anti-inflammatory drugs in human health issues. The macrophage cell line RAW 264.7 and the fibroblast cell line L929 were incubated for $24 \mathrm{~h}$ with various dilutions of the two extracts (from 5 to $100 \mu \mathrm{g} / \mathrm{mL}$ ) and then the cell viability was evaluated by the MTT test and compared to untreated, control cells (Figure 5A and B, respectively). The results showed that, for both cell lines, the ethanolic extract never affected the cell viability at all concentrations tested (Figure 5A, RAW 264.7 macrophages; Figure 5B L929 fibroblasts; square indicator, respectively). The ethanolic extract also showed a slight cell number increase at 10 and $50 \mu \mathrm{g} / \mathrm{mL}$ concentration ( $p<0.05$ for both compared to control) indicating that this extract may be safely used in humans. Conversely, the DMSO extract showed a significant impairment of cell viability at $24 \mathrm{~h}$, but only at the highest concentration $(100 \mu \mathrm{g} / \mathrm{mL})$, in both cell lines (66\% mortality in RAW 264.7 macrophages, $p<0.001$ compared to C, and $50 \%$ cell mortality in L929 fibroblasts; triangle indicator, $p<0.005$ compared to the control, respectively). At concentrations $\leq 50 \mu \mathrm{g} / \mathrm{mL}$ the DMSO extract could be also considered reasonably safe in both cell lines (Figure 5A and B, triangle indicator, $p<0.084$ and $p<0.15$ for $50 \mu \mathrm{g} / \mathrm{mL}$ compared to control in each cell line, respectively). Our results differ from those reported by Stanojkovic et al. [35] on C. amentacea extracts from the Adriatic Sea, showing a significant cytotoxic potential on different tumor cell lines $\left(\mathrm{EC}_{50}<30 \mu \mathrm{g} / \mathrm{mL}\right.$ in human breast cancer cells, and $\mathrm{EC}_{50}<100 \mu \mathrm{g} / \mathrm{mL}$ in human cervix and human colon carcinomas). This discrepancy can be ascribed to the different conditions used by Stanojkovic et al. where a Soxhlet extractor with acetone as solvent was used, retrieving a more hydrophobic fraction of algal metabolites, with respect to our mild extraction conditions, and this could explain the different results of the Ligurian Sea species compared to those from the Adriatic Sea. Indeed, a certain degree of toxicity was also observed in our DMSO extracts, retrieving a more organic fraction and, consequently closer to the acetone extraction of the group of Stanojkovic. In our conditions in fact, we obtained EC50 values of 83 and $103.6 \mu \mathrm{g} / \mathrm{mL}$ for RAW 264.7 macrophages and L929 fibroblasts, respectively. A significant cytotoxic activity in organic extracts has also been demonstrated in other Cystoseira species, as for instance, in C. tamariscifolia hexane and diethylether extracts [39] that showed an $\mathrm{EC}_{50}<30 \mu \mathrm{g} / \mathrm{mL}$ on tumor cell lines, and also in C. barbata acetone extracts [41] that showed an $\mathrm{EC}_{50}<100 \mu \mathrm{g} / \mathrm{mL}$ on MCF7 mammary adenocarcinoma cells. Overall, our results demonstrate that the ethanolic and DMSO extracts from C. amentacea, that was collected in the Ligurian Sea, could be safely used as nutraceuticals or cosmeceuticals since they have revealed no grade, or extremely low grade of toxicity and a potent antioxidant activity. These features may be exploited for the formulation of new biologically active additives in dietary supplements, for instance in the elderly, or, in cosmetic products for skin treatments, where the antioxidants exert significant anti-aging 
effects. Indeed, besides the antioxidant and anti-inflammatory potential demonstrated in our study, the Cystoseira sensu lato extracts display other important features exploitable as ingredients in functional foods that have been already disclosed in previous studies, such as (i) in vivo antidiabetic properties of lipid and phenolic extracts [49], (ii) in vivo liver protection, inhibition of lipase activity and body weight lowering of sulphate polysaccharide extracts [50] and (iii) high PUFA/FA ratio in Cystoseira fatty acid content, with consequent low atherogenic and thrombogenic indexes [43,51]. Overall, these features indicate a high nutraceutical value of the algal extracts that could be realistically exploited by the industry. Finally, in addition to the antioxidant and anti-inflammatory properties, the cosmetic use of Cystoseira extracts for lenitive skin concoctions would take advantage of a documented antimicrobial activity, indicating that the extracts could exert a certain grade of protection from skin infections $[38,43]$ and also an anti-hyaluronidase activity [52] that could help in the maintenance of dermal thickness, which thinning is one of the most important negative aspects of skin aging.

\subsection{Cell Death Rescue and Intracellular ROS Scavenging of C. amentacea Extracts}

Since in our conditions, the ethanolic and DMSO extracts were not toxic at $100 \mu \mathrm{g} / \mathrm{mL}$ and $50 \mu \mathrm{g} / \mathrm{mL}$, respectively, these values were the respective highest concentrations, used in the following experiments. In detail, the effectiveness of the antioxidant and anti-inflammatory activity of the two extracts in in vitro cellular models of toxicity and inflammation was evaluated. The rescue from $\mathrm{H}_{2} \mathrm{O}_{2}$-induced cell death was evaluated in both RAW 264.7 macrophages and L929 fibroblasts in the presence of the two extracts after $24 \mathrm{~h}$ strong oxidant challenge with $500 \mu \mathrm{M} \mathrm{H}_{2} \mathrm{O}_{2}$ (Figure $5 \mathrm{C}$ and D, respectively). In the RAW 264.7 cell line after $\mathrm{H}_{2} \mathrm{O}_{2}$ treatment only a $23.9 \%$ cell survival was observed compared to control, which was only slightly higher in the ethanolic extracts treated cells (Figure 5C; 35.2 at 50 and $38.6 \%$ at $10 \mu \mathrm{g} / \mathrm{mL}$, square indicator, $p<0.05$ for both extracts, compared to $\mathrm{H}_{2} \mathrm{O}_{2}$ treatment) and significantly higher in the DMSO extracts (Figure $5 \mathrm{C}$; 53.8 at 50 and $42.5 \%$ at $10 \mu \mathrm{g} / \mathrm{mL}$, triangle indicator, $p<0.01$ for both extracts compared to $\mathrm{H}_{2} \mathrm{O}_{2}$ treatment). On the contrary, in the $\mathrm{L} 929$ fibroblast cell line, where $\mathrm{H}_{2} \mathrm{O}_{2}$ treatment, compared to the control lead to a $32 \%$ cell survival, it was never possible to observe a beneficial effect in cell viability in the presence of the two extracts at all concentrations tested (Figure 5D), indicating a certain variability in the effects of the C. amentacea extracts towards different cell types. Notably, macrophages with respect to fibroblasts are highly reactive immune cells, which undergo a rapid functional production of ROS upon activation by pro-inflammatory stimuli. Therefore, the positive results on cell rescue of $\mathrm{H}_{2} \mathrm{O}_{2}$-challenged RAW 264.7 macrophages seem more meaningful for the possible use of the extracts as anti-inflammatory drugs, since ROS production by macrophages is indeed physiologically more relevant, more frequent and more dangerous than in other cell types in the human organism.

To evaluate the anti-inflammatory potential of $C$. amentacea extracts, the inhibition of the respiratory burst measured by quantification of intracellular ROS production after $\mathrm{H}_{2} \mathrm{O}_{2}$ challenge in both RAW 264.7 macrophages and L929 fibroblasts (Figure 6A and B, respectively) was quantified. 

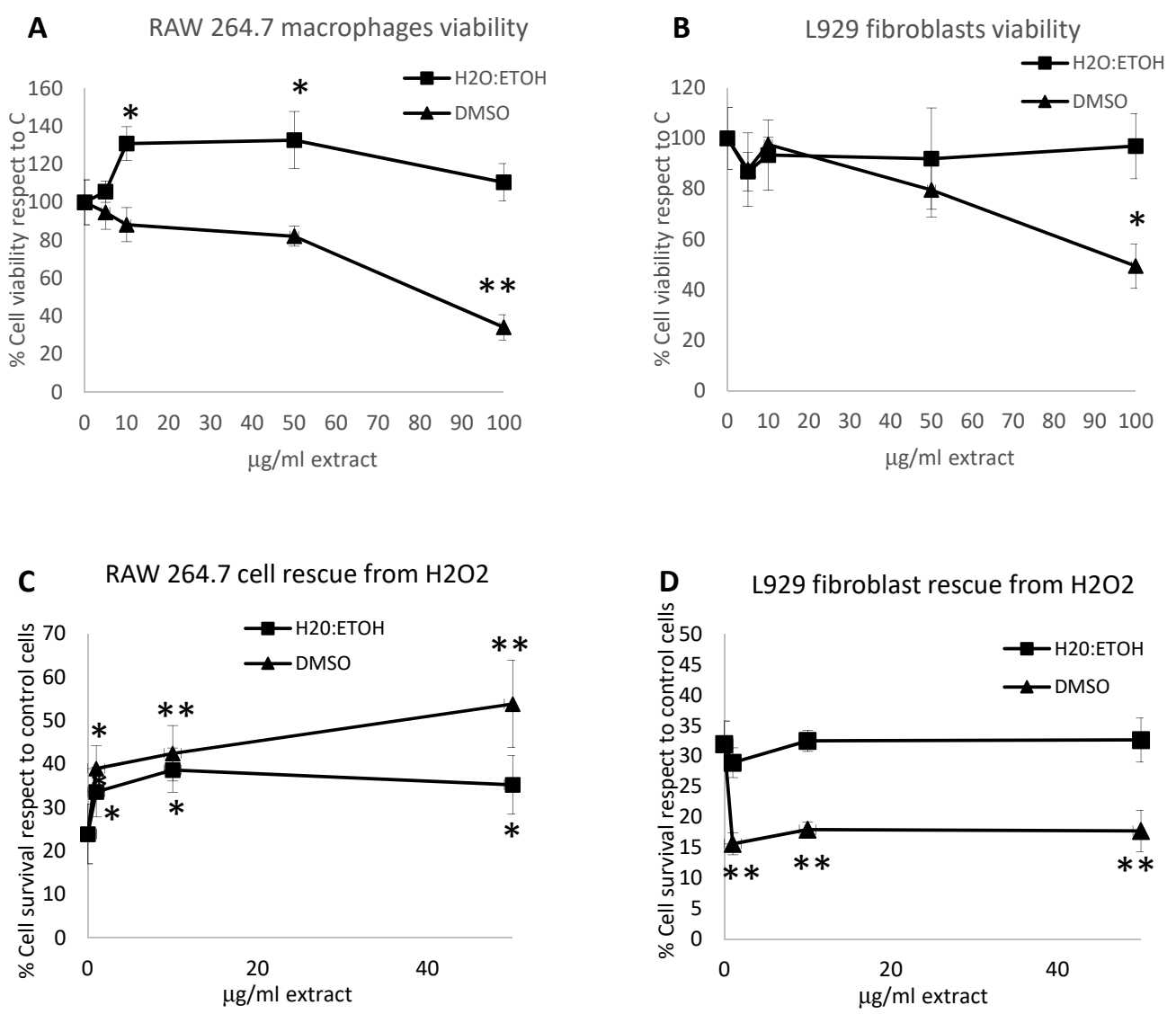

Figure 5. Toxicity evaluation. (A) RAW 264.7 cell growth quantitative evaluation, by the cell viability MTT test at 24 h, in the presence of increasing concentrations of $C$. amentacea $50 \%$-ethanol (black square indicator) and DMSO (black triangle indicator) extracts. Results are expressed as cell percentage respect to control, untreated cells (in presence of vehicle) and are the mean \pm S.D. of three experiments performed in quadruplicate. Asterisks indicate significance in paired Tukey test (ANOVA, $p<0.05$; Tukey vs. C: ${ }^{*} p<0.05,{ }^{* *} p<0.001$, respectively). (B) L929 fibroblast cell growth quantitative evaluation, in the same conditions as (A). Black square indicator: 50\%-ethanol extract, black triangle indicator: DMSO extract. The results are expressed as cell percentage respect to control, untreated cells and are the mean \pm S.D. of three experiments performed in quadruplicate. Asterisks indicate significance in paired Tukey test (ANOVA, $p<0.05$; Tukey vs. C: ${ }^{*} p<0.005$, respectively). (C) Cell death rescue from $500 \mu \mathrm{M} \mathrm{H}_{2} \mathrm{O}_{2}$-challenge of RAW 264.7 macrophages in presence of $50 \%$-ethanol (black square indicator) and of DMSO (black triangle indicator) extracts, evaluated by MTT test at 24 h. The results are expressed as cell percentage respect to control, untreated cells and are the mean \pm S.D. of two experiments performed in quadruplicate. Asterisks indicate significance in paired Tukey test (ANOVA, $p<0.05$; Tukey vs. $\mathrm{H}_{2} \mathrm{O}_{2}:{ }^{*} p<0.05,{ }^{* *} p<0.01$, respectively). (D) Cell death rescue from $500 \mu \mathrm{M} \mathrm{H}_{2} \mathrm{O}_{2}$-challenge of L929 fibroblasts, in the same conditions as (A). Black square indicator: 50\%-ethanol extract, black triangle indicator: DMSO extract. Results are expressed as cell percentage respect to control, untreated cells and are the mean \pm S.D. of two experiments performed in quadruplicate. Asterisks indicate significance in paired Tukey test (ANOVA, $p<0.05$; Tukey vs. $\mathrm{H}_{2} \mathrm{O}_{2}$ : ${ }^{* *} p<0.005$ ). 

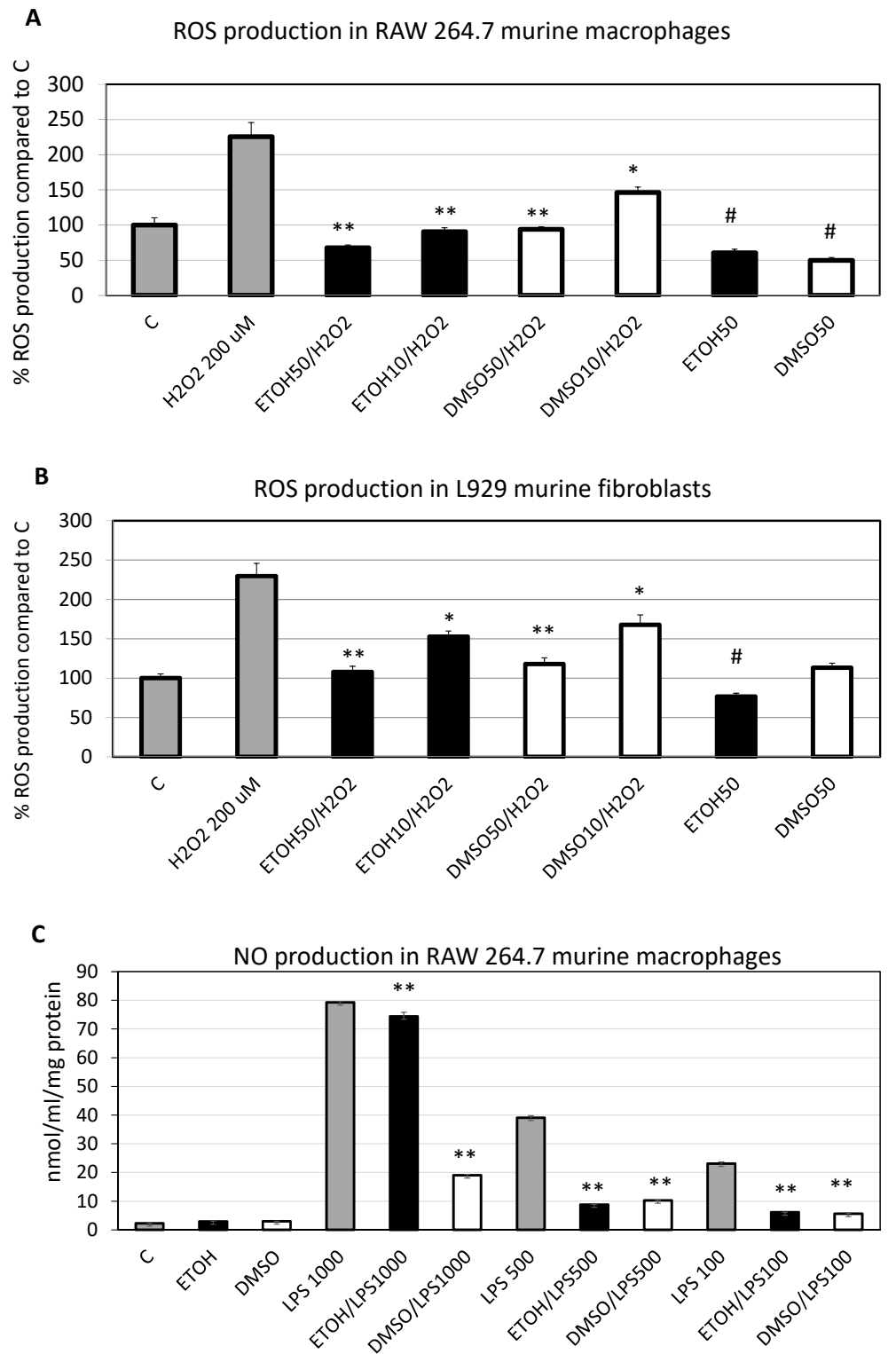

Figure 6. amentacea extract ROS and NO scavenging activity in cellular assays. (A) Intracellular ROS production measured by DCF fluorometric analysis in RAW 264.7 murine macrophages incubated for $2 \mathrm{~h}$ with $200 \mu \mathrm{M} \mathrm{H}_{2} \mathrm{O}_{2}$ (positive control) in presence or absence of 50 and $10 \mu \mathrm{g} / \mathrm{mL}$ of $50 \%$-ethanol (black bars), or DMSO (white bars) extracts, respectively. The results are expressed as percentage of ROS production respect to control, untreated cells (in presence of vehicle) and are the mean \pm SD of three experiments performed in quadruplicate. Asterisks indicate significance in Tukey test (ANOVA $p<0.0001$; Tukey vs. $\mathrm{H}_{2} \mathrm{O}_{2},{ }^{*} p<0.05$, ${ }^{* *} p<0.005$, respectively; Tukey vs. $\mathrm{C} \# p<0.05$ ). (B) Intracellular ROS production in L929 cells in the same conditions as (A). Results are expressed as percentage of ROS production respect to control, untreated cells and are the mean \pm SD of three experiments performed in quadruplicate. Asterisks indicate significance in Tukey test (ANOVA $p<0.00001$; Tukey vs. $\mathrm{H}_{2} \mathrm{O}_{2},{ }^{*} p<0.005$, ${ }^{* *} p<0.0001$, respectively; Tukey vs. $\left.\mathrm{C} \# p<0.05\right)$. (C) Quantification by Griess assay of NO production in the cell medium of RAW 264.7 macrophages stimulated for $24 \mathrm{~h}$ by increasing concentrations of LPS (grey bars, 100-500-1000 $\mathrm{ng} / \mathrm{mL}$ ) in the presence of $100 \mu \mathrm{g} / \mathrm{mL} \mathrm{50 \% -ethanol} \mathrm{(black} \mathrm{bars)} \mathrm{or} 50 \mu \mathrm{g} / \mathrm{mL}$ DMSO (white bars) extract. Results are expressed as nmol of $\mathrm{NO}$ production $/ \mathrm{mL}$ medium $/ \mathrm{mg}$ total cellular protein and are the mean $\pm \mathrm{SD}$ of three experiments performed in duplicate. Asterisks indicate significance in Tukey test (ANOVA $p<0.00001$; Tukey vs. the respective LPS concentration ${ }^{* *} p<0.0001$ ). 
The quantification of intracellular ROS production after $2 \mathrm{~h}$ of $200 \mu \mathrm{M} \mathrm{H}_{2} \mathrm{O}_{2}$ stimulation revealed that the percentage of ROS production in RAW 264.7 cells was $225 \%$, compared to the control cells (Figure 6A, "H2O2 $200 \mu \mathrm{M}$ " bar vs. " $\mathrm{C}$ " bar, $p<0.01$ ). This production was completely inhibited by the ethanolic extract at both concentrations tested, namely 50 and $10 \mu \mathrm{g} / \mathrm{mL}$ (Figure 6A, "ETOH50/H2O2" and "ETOH10/H2O2" bars, $p<0.005$ for both, compared to " $\mathrm{H} 2 \mathrm{O} 2200 \mu \mathrm{M}$ ", respectively). Instead, the inhibition in presence of the DMSO extract was complete only at the highest concentration tested (50 $\mu \mathrm{g} / \mathrm{mL}$, "DMSO50/H2O2" $p<0.005$ compared to "H2O2 $\left.200 \mu \mathrm{M}^{\prime}\right)$ and partial at the lowest $(10 \mu \mathrm{g} / \mathrm{mL}$, "DMSO10/H2O2" bar, 63\% inhibition respect to "H2O2 $200 \mu \mathrm{M}$ " bar, $p<0.05)$. Furthermore, administration of the two extracts alone was able per se to significantly lower also the basal ROS production in RAW 264.7 macrophages (40\% inhibition for "ETOH50" and 51\% inhibition for "DMSO50" bars, compared to control, $p<0.05$ for both). The same experiment was performed in L929 fibroblasts and, also in this case, inhibition of intracellular ROS production after $\mathrm{H}_{2} \mathrm{O}_{2}$ administration to cells in the presence of the two extracts was obtained, showing a lower efficiency compared to RAW 264.7 macrophages (Figure 6B vs. A, respectively). Similarly to macrophages, $\mathrm{H}_{2} \mathrm{O}_{2}$-stimulated fibroblasts after $2 \mathrm{~h}$ raised the intracellular ROS production to $230 \%$ compared to control cells (Figure 6B, "H2O2 $200 \mu \mathrm{M}$ " bar vs. "C" bar, $p<0.0001$ ) and this overproduction was completely suppressed by both extracts at the highest concentration of $50 \mu \mathrm{g} / \mathrm{mL}$ (Figure 4B, "ETO50/H2O2" and "DMSO50/H2O2" bars, respectively, $p<0.0001$ for both compared to "H2O2 $\left.200 \mu \mathrm{M}^{\prime \prime}\right)$, while only partially at the lowest concentration (60\% for "ETOH10/H2O2" bar and 48\% for "DMSO10/H2O2" bar respect to "H2O2 $200 \mu \mathrm{M}$ " bar, $p<0.005$ for both). Finally, only the ethanolic extract per se was able to slightly diminish intracellular basal ROS production in L929 fibroblasts respect to control cells by $24 \%$ ("ETOH50" bar vs. " $\mathrm{C}^{\prime}, p<0.05$ ). Stanojkovic et al. [35] report that $C$. amentacea acetone Soxhlet extracts also showed a partial decrease of ROS production by $\mathrm{H}_{2} \mathrm{O}_{2}$-challenged erythrocytes and polymorphonuclear granulocytes but, in this case using different types of cells and performing a qualitative assessment, no precise quantification of the intracellular ROS inhibition was performed. Therefore, to our knowledge, the present study reports, for the first time, a remarkable intracellular antioxidant potential of the extracts from an alga belonging to the genus Cystoseira, indicating that the secondary metabolites purified by our ethanolic and DMSO extracts are able to cross cell membranes and act at the level of the cytoplasm. This is a major finding because it clearly indicates the effectiveness of these extracts as potential drugs in human cells when the physiological oxidative balance is impaired.

\subsection{Anti-Inflammatory Potential of C. amentacea Extracts}

RAW 264.7 macrophages were stimulated with increasing concentrations of the highly pro-inflammatory bacterial endotoxin ("LPS" bars, from 100 to $1000 \mathrm{ng} / \mathrm{mL}$ ) and the NO production was evaluated after incubation in the presence or absence of the two C. amentacea extracts (Figure 6C). At the same time, the overexpression of inflammatory cytokines, Tumour Necrosis Factor- $\alpha$ (TNF- $\alpha$ ), Cyclooxygenase-2 (COX-2), inducible NO synthase (iNOS), Interluekin-1 $\beta$ (IL-1 $\beta$ ) and interleukin-6 (IL-6), was evaluated by quantitative PCR (qPCR, Figure 7) to finally assess the real anti-inflammatory potential of the two concoctions. After $24 \mathrm{~h}$, LPS stimulation lead to a significant $\mathrm{NO}$ overproduction in RAW 264.7 macrophages at all concentrations of endotoxin used (Figure 6C, 79.3, 39.1 and $23.1 \mathrm{nmol} / \mathrm{mL} / \mathrm{mg}$ protein for stimulation with LPS 1000, 500 and $100 \mathrm{ng} / \mathrm{mL}$, respectively) compared to control cells ( $p<0.0001$ for the three LPS concentrations) in which the production was almost undetectable (Figure $6 \mathrm{C}$, “ $\mathrm{C}$ " bar). This NO production was completely inhibited by both ethanolic and DMSO extracts when LPS was used at the lowest concentration ("ETOH/LPS100" and "DMSO/LPS100" bars versus "LPS100" bar, respectively, $p<0.0001$ for both). Furthermore, the NO overproduction was strongly inhibited by the two extracts in presence of the intermediate LPS concentration $(500 \mathrm{ng} / \mathrm{mL}$, "LPS500" bar vs. "ETOH/LPS500" bar, 81.7\% inhibition, and versus "DMSO/LPS500" bar, 
$77.8 \%$ inhibition, respectively, $p<0.0001$ for both). Finally, at the highest LPS concentration (1000 ng/mL) only the DMSO extract retained the ability to drastically inhibit the NO production in RAW 264.7 macrophages ("LPS1000" bar vs. "DMSO/LPS1000" bar, 78\% inhibition, $p<0.0001)$, while the ethanolic extract only exhibited a slight, but still significant NO reduction (6.3\% inhibition, “ETOH/LPS1000" bar vs. "LPS1000", $p<0.0001)$. To our knowledge, this is the first demonstration that the extracts from an alga of the Cystoseira genus are capable of scavenging the natural, and potentially dangerous, direct production of $\mathrm{NO}$ by activated macrophages, again indicating a major anti-inflammatory effect in a more physiological setting like a cell culture, with respect to a cell-free spectrophotometric assay, such as the nitroprusside one, usually used in other studies [42].

Finally, we investigated the inhibition of gene expression upregulation of well-known inflammatory markers, after LPS stimulation of RAW 264.7 macrophages, in the presence of the two extracts, and also in this case, we could observe a dramatic anti-inflammatory effect of the $C$. amentacea derived mixture products towards IL1- $\beta$, IL-6, iNOS and COX-2 upregulation, as well as a partial inhibitory effect on TNF- $\alpha$ overexpression (Figure 7). In particular, the TNF- $\alpha$ mRNA was overexpressed by 12.7 -fold and 14-fold after $8 \mathrm{~h}$ stimulation with LPS 100 and $500 \mathrm{ng} / \mathrm{mL}$ compared to control cells, respectively (Figure 7A, "LPS100" and "LPS500" bars vs. "C", $p<0.005$ for both). This overexpression was partially inhibited only by the ethanolic extract by 29.8 and $34.7 \%$ at the two LPS concentrations, respectively ("ETOH/LPS100" and "ETOH/LPS500" bars, $p<0.005$ for both, compared to the respective LPS). Conversely, for the DMSO extract, it was not possible to observe any TNF- $\alpha$ overexpression inhibition at both LPS concentrations used. That was probably a consequence of the property of the DMSO extract that per se increases significantly the TNF- $\alpha$ expression by 9.1 folds compared to control cells ("DMSO" bar versus " $\mathrm{C}$ "). Concerning IL$1 \beta$ upregulation, in the presence of LPS, a strong induction of gene expression was observed in RAW 264.7 macrophages, at both LPS concentrations used (Figure 7B, 5386-fold increase for "LPS100" and 6833-folds for "LPS500", respectively, $p<0.0001$ for both, compared to the control). This increase was significantly inhibited by both the ethanolic and DMSO extracts at the lowest LPS concentration, by $42 \%$, and 73\%, respectively ("ETOH/LPS100" and "DMSO/LPS100" bars vs. "LPS100", $p<0.001$ and $p<0.0005$, respectively), while at the highest LPS concentration, only the DMSO extract retained the ability to inhibit the expression of this cytokine by 67.7\% ("DMSO/LPS500" vs. “LPS500", p < 0.0005). IL-6 strong upregulation, in the presence of LPS, was observed in RAW 264.7 macrophages, at both LPS concentrations used (Figure 7C, 2120-fold increase for "LPS100" and 2317-folds for "LPS500" $p<0.005$ and $p<0.0001$, compared to $C$, respectively). This increase was significantly inhibited by both the ethanolic and DMSO extracts at the lowest LPS concentration, by $29 \%$ and $84 \%$ respectively ("ETOH/LPS100" and "DMSO/LPS100" bars vs. "LPS100", $p<0.05$ and $p<0.005$, respectively), while at the highest LPS concentration, none of the extracts were able to affect IL-6 overexpression. Since the three abovementioned cytokines, TNF- $\alpha$, IL- $1 \beta$ and IL- 6 are important inflammatory mediators, propagating the signals and recruiting more inflammatory cells, their significant inhibition at the mRNA level in our in vitro inflammatory simulator test by use of the C. amentacea extracts, suggests promising effects also in in vivo settings where the goal is always to abate these signals in order to resolve the inflammatory state [4-6]. Another important mediator of inflammation is $\mathrm{PGE}_{2}$, produced by the inducible enzyme cyclooxygenase-2 (COX-2). This molecule is responsible of many outcomes of acute inflammation like vasodilatation, oedema, influx of neutrophils and macrophages at the site of inflammation, increase of pain sensory response, and pyrogenic effect [53]. Thus, inhibition of $\mathrm{PGE}_{2}$ production is the main target of numerous anti-inflammatory drugs named NSAIDS (nonsteroidal anti-inflammatory drugs). These products in the years have shown many undesired side effects, thus there is a need in the pharmaceutical market of new, safer products, with selective action and lower toxicity which can be obtained from plants and isolated phytoconstituents [54]. The investigation of COX-2 mRNA expression in our in vitro inflammatory simulator test showed that both LPS concentrations were able to strongly upregulate this important 
inflammatory mediator, by 84.3 folds and 132.5 folds compared to control cells (Figure 7D, "LPS100" and "LPS500" bars vs. "C", respectively, $p<0.0001$ for both). At both LPS concentrations, both $C$. amentacea extracts were able to inhibit COX-2 mRNA synthesis. In particular, at $100 \mathrm{ng} / \mathrm{mL}$ LPS stimulation there was a significant inhibition of COX-2 upregulation by $36 \%$ in presence of the ethanolic extract and by $83 \%$ in presence of the DMSO extract ("ETOH/LPS100" and "DMSO/LPS100" bars vs. "LPS100", $p<0.01$ and $p<0.0001$, respectively). At $500 \mathrm{ng} / \mathrm{mL}$ LPS stimulation, the two extracts inhibition was of $47.3 \%$ for the ethanolic and of $88.8 \%$ for the DMSO extract, respectively ("ETOH/LPS500" and "DMSO/LPS500" bars vs. "LPS500", $p<0.01$, and $p<0.0001$, respectively). This significant effect for COX-2 expression again indicates the possibility to use these extracts as efficient anti-inflammatory drugs. Furthermore, since the effect is at the level of the mRNA synthesis, many of the side effects of traditional NSAIDS could be probably avoided by use of $C$. amentacea extracts. In fact, NSAIDS usually act as cyclooxygenase enzyme inhibitors acting both on COX-1 and COX-2 isoforms, and negative effects are usually due to inhibition of COX-1 isoform physiological role [54], which in the case of our extracts, would not be affected. Finally, also iNOS overexpression, responsible for the high levels of the cytotoxic NO radical in macrophages, was investigated. In RAW 264.7 cells both LPS concentrations were able to strongly upregulate this important enzyme, by 94.6 folds and 102.1 folds compared to control cells (Figure 7E, "LPS100" and "LPS500" bars vs. "C", $p<0.001$ and $p<0.0001$, respectively). Even in this case, both extracts were able to inhibit overstimulated iNOS mRNA synthesis. In fact, at $100 \mathrm{ng} / \mathrm{mL}$ LPS stimulation there was a significant inhibition of iNOS by $78 \%$ with the ethanolic extract and by $90 \%$ with the DMSO extract ("ETOH/LPS100" and "DMSO/LPS100" bars vs. "LPS100", $p<0.005$ and $p<0.001$, respectively). Conversely, at $500 \mathrm{ng} / \mathrm{mL}$ LPS stimulation, the ethanolic extract was able to inhibit iNOS overexpression by 73\% and the DMSO extract by $29 \%$ ("ETOH/LPS500" and "DMSO/LPS500" bars vs. "LPS500", $p<0.005$ and $p<0.05$, respectively). These data on iNOS inhibition are particularly interesting since they demonstrate for the first time that, other than a direct antioxidant effect exerted by scavenging the excess of NO produced by this enzyme, the $C$. amentacea extracted metabolites can also inhibit the preceding iNOS mRNA synthesis and protein production, de facto annihilating NO damage potential.

The fact that $C$. amentacea extracts exerts these significant inhibitory effects on so numerous essential inflammatory mediators, such as TNF, cytokines, prostaglandin synthase and nitric oxide synthase enzymes, suggests that the action of the extracts may be upstream of the main signal transduction pathways, leading to macrophage activation and a consequent change of gene expression profiles. One of the main, and well demonstrated, actions of the extracts is a potent ROS scavenging activity in cell-free as well as in cellular models (see Figures 1, 2 and 4). Since various ROS such as hydroxyl radical, superoxide anion and hydrogen peroxide, produced immediately after inflammatory stimuli by NADPH oxidase activation, are considered upstream signals able to activate both NF- $\mathrm{kB}$ as well as the MAPK signaling $[55,56]$ responsible for the majority of downstream cell inflammatory response, the scavenging of ROS production by $\mathrm{C}$. amentacea extracts in the cells at the very beginning of the inflammatory response is likely the reason for the strong inhibitory effects on macrophage activation in our in vitro inflammatory simulator test.

The only data reported in the literature, showing an anti-inflammatory effect of extracts of the Cystoseira genus on a physiological model of inflammation, are those from Mhadhebi et al. [34] where C. compressa, C. crinita and C. sedoides aqueous extracts showed a beneficial effect, similar to dexamethasone treatment, on the rat paw oedema test, confirming the potential of extracts of the same genus also in an in vivo setting, although in that case the cellular and molecular mechanism of action of the extracts was not investigated. 
A

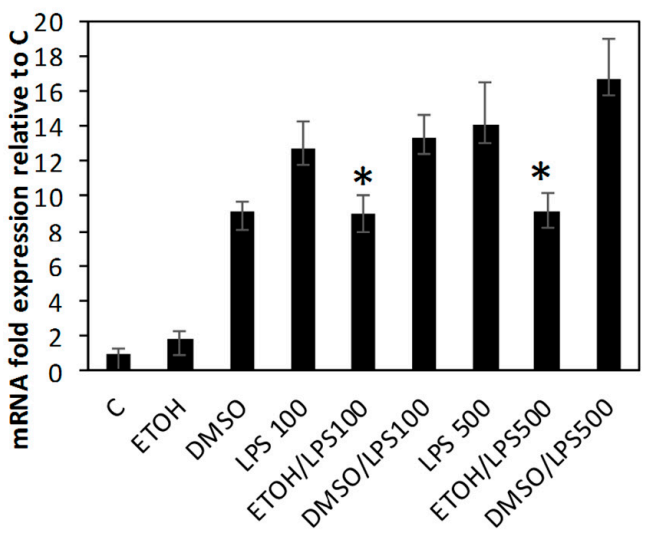

C

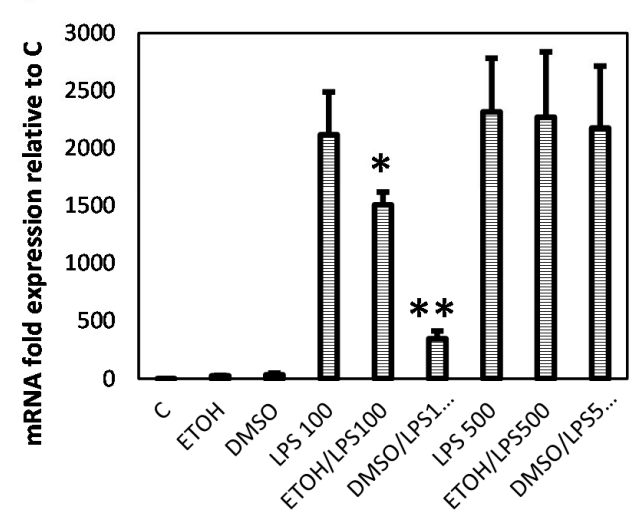

B

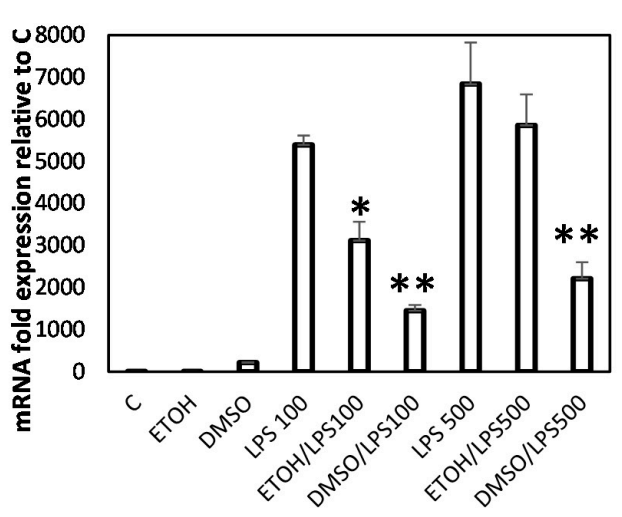

D

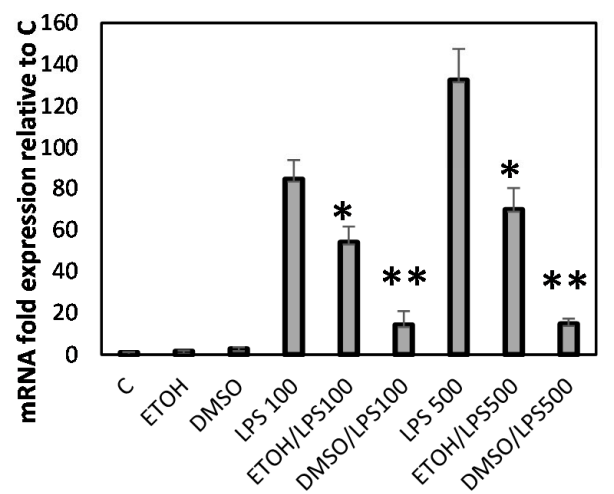

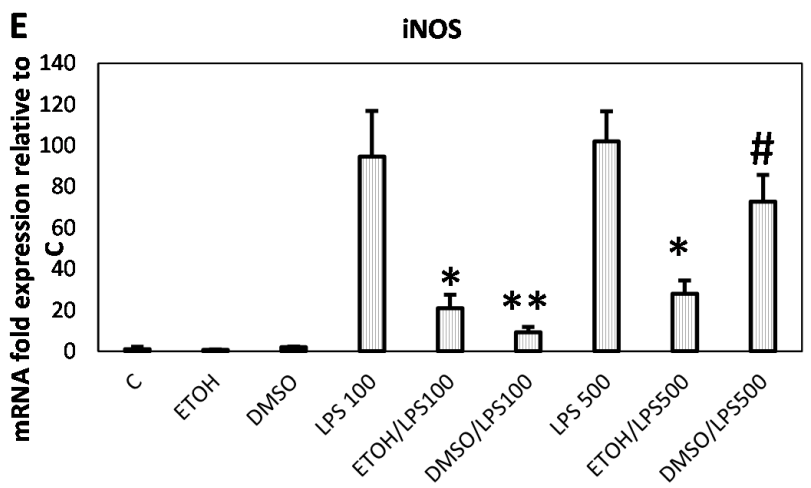

Figure 7. amentacea extract inhibition of gene expression in LPS-stimulated RAW 264.7 macrophages. Gene expression measured by qPCR analysis of TNF-alpha (A), IL-1ß (B), IL-6 (C), COX-2 (D) and iNOS (E) after RAW 264.7 cell incubation, for $8 \mathrm{~h}$, with or without increasing concentrations of LPS (100-500 ng/mL) and in presence of $100 \mu \mathrm{g} / \mathrm{mL} \mathrm{50 \% -ethanol}$ extract or of $50 \mu \mathrm{g} / \mathrm{mL}$ of DMSO extract. Data are normalized on the GAPDH housekeeping gene and expressed as mRNA fold increase compared to control, untreated cells (in the presence of vehicle). Results are the mean $\pm \mathrm{SD}$ of three experiments performed in triplicate. Asterisks indicate significance in Tukey test (TNF-alpha ANOVA $p<0.00001$, Tukey vs. the respective LPS concentration, ${ }^{*} p<0.005$; IL-1beta ANOVA $p<0.00001$, Tukey vs. the respective LPS concentration, ${ }^{*} p<0.001 ;{ }^{* *} p<0.0005$, respectively; IL-6 ANOVA $p<0.0001$, Tukey vs. the respective LPS concentration, ${ }^{*} p<0.05$; ${ }^{* *} p<0.005$, respectively; COX-2 ANOVA $p<0.00001$, Tukey vs. the respective LPS concentration, ${ }^{*} p<0.01 ;{ }^{* *} p<0.0001$, respectively; iNOS ANOVA $p<0.00001$, Tukey vs. the respective LPS concentration, $\# p<0.05 ;{ }^{*} p<0.005 ;{ }^{* *} p<0.001$, respectively). 


\section{Conclusions}

The data obtained in this study demonstrate the strong anti-inflammatory effect of two C. amentacea extracts (DMSO and ethanolic) from the Ligurian Sea (North-western Mediterranean), by molecular and cellular analyses. The extracts showed a plethora of antioxidant and anti-inflammatory effects that were, for the first time, thoroughly investigated in this study by cell-free spectrophotometric tests, but most importantly, by the use of cellular models of toxicity and inflammation. The pleiotropic effects of the extracts in the well-known inflammatory model of LPS-stimulated RAW 264.7 macrophages point out the capacity of the metabolites, contained in the extracts, to act at different levels of the inflammatory process, both by abating the respiratory burst leading to the excess ROS production typical of the initial phase of the inflammatory response by immune cells, and also in the following phase, by blocking the production and release of important mediators propagating and exacerbating the process. Furthermore, the low cellular toxicity demonstrated by the two extracts opens the way to the use, in the near future, of its bioactive principles also for the formulation of antioxidant nutraceutical concoctions for anti-aging purposes as well as of cosmetic lotions for lenitive and restorative treatments to cure skin inflammatory states.

\section{Materials and Methods}

\subsection{Chemicals}

Here is the list of all reagents used: Dimethyl sulfoxide (DMSO), Ethanol, FolinCiocalteu reagent, Sodium Carbonate $\left(\mathrm{Na}_{2} \mathrm{CO}_{3}\right)$, Gallic Acid, Aluminium Chloride $\left(\mathrm{AlCl}_{3}\right)$, Sodium Nitrite $\left(\mathrm{NaNO}_{2}\right)$, Sodium Hydroxide $(\mathrm{NaOH})$, Quercetin, Formic Acid (FOA), Methanol, 2,2-diphenyl-1-picrylhydrazyl (DPPH), Phosphate buffer, Potassium Ferricyanide $\left(\mathrm{K}_{3}\left[\mathrm{Fe}(\mathrm{CN})_{6}\right]\right)$, Trichloroacetic Acid (TCA), Ferric Chloride $\left(\mathrm{FeCl}_{3}\right)$, Ascorbic Acid, Ethylenediaminetetraacetic acid (EDTA), Ferrous Ammonium Sulphate $\left(\left(\mathrm{NH}_{4}\right)_{2} \mathrm{Fe}\left(\mathrm{SO}_{4}\right)_{2}\right)$, Ammonium Acetate, Acetic Acid, Acetylacetone, Sodium Nitroprusside, Sulphanilamide, Naphthyl-ethylene-diamine, Orto-phosphoric Acid $\left(\mathrm{H}_{3} \mathrm{PO}_{4}\right)$, Dulbecco's modified Eagle's medium (D-MEM), Glutamine, Fetal Bovine Serum (FBS), Penicillin, Streptomycin, 3-(4,5dimethylthiazol-2-yl)-2,5-diphenyltetrazolium bromide (MTT), Hydrogen Peroxide $\left(\mathrm{H}_{2} \mathrm{O}_{2}\right)$, Bacterial Lipopolysaccharide (LPS), 1,4-Dithiothreitol (DTT), Sodium Dodecyl Sulphate (SDS), Glycerol, Tris(hydroxymethyl)aminomethane hydrochloride (TRIS-HCl), Hank's Balanced Salt Solution (HBSS), 2', $7^{\prime}$-dichloro-dihydro-fluorescein diacetate (DCF).

All reagents were acquired from SIGMA-ALDRICH (Milan, Italy), unless otherwise stated.

\subsection{Algae Collection}

In the Ligurian Sea (Northwestern Mediterranean), fronds of Cystoseira amentacea were collected in the midlittoral zone, on exposed rocky shores, at Bogliasco, Genoa (NW Italy, $442^{\circ} 2^{\prime} 40.37^{\prime \prime} \mathrm{N}-9^{\circ} 4^{\prime} 35.14^{\prime \prime} \mathrm{E}$ ). The collection was performed in summer 2017, when the sea temperature values oscillated between 25 and $26^{\circ} \mathrm{C}$. After collection, fronds were stored in plastic bags kept in cold conditions and immediately transported to the laboratory at the University of Genova.

\subsection{Production of Extracts from Cystoseira amentacea}

C. amentacea fronds were washed with deionized water, air-dried and cut to tiny pieces, and then dried in a lyophilizer. The extracts were obtained by incubation in mild conditions for $48 \mathrm{~h}$ in the dark in a rotary disk shaker at $30^{\circ} \mathrm{C}$ of $2 \mathrm{~g}$ of lyophilized fronds in $20 \mathrm{~mL}$ of two different solvents:

- Dimethyl sulfoxide (DMSO)

- $50 \%$ ETHANOL

At the end of the extraction the suspensions were filtered with a strainer, an aliquot was lyophilized and weighted to determine the quantity of molecules extracted with the 
two solvents and finally they were diluted to a starting concentration of $5 \mathrm{mg} / \mathrm{mL}$. Storage was done at $-20^{\circ} \mathrm{C}$.

\subsection{Total Phenolic Content}

The total phenolic content (TPC) was determined according to the Folin-Ciocalteu assay reported by Biju et al. [57]. Briefly, the reaction mixture contained $100 \mu \mathrm{L}$ of C. amentacea extracts ( $5 \mathrm{mg} / \mathrm{mL}$ starting concentration), $800 \mu \mathrm{L}$ of deionized water and $100 \mu \mathrm{L}$ of Folin-Ciocalteu phenol reagent. After $5 \mathrm{~min}$ of incubation at R.T., $1 \mathrm{~mL}$ of $10 \% \mathrm{Na}_{2} \mathrm{CO}_{3}$ solution was added to the mixture. After incubation for $60 \mathrm{~min}$ in the dark at R.T, absorbance at $550 \mathrm{~nm}$ was read with a Beckman spectrophotometer (DU 640). Phenolic concentration was obtained by comparison with a calibration curve based on different concentrations of gallic acid ( 0.05 to $20 \mu \mathrm{g} / \mathrm{mL}$ ), and the total phenolic content was expressed as mg Gallic acid Equivalents (GAE).

\subsection{Total Flavonoid Content}

Total flavonoid content (TFC) was measured by the $\mathrm{AlCl}_{3}$ colorimetric assay reported by Biju et al. [57]. The test solution was prepared with $100 \mu \mathrm{L}$ of C. amentacea extracts ( $5 \mathrm{mg} / \mathrm{mL}$ starting concentration), $400 \mu \mathrm{L}$ of distilled water and $30 \mu \mathrm{L}$ of $5 \% \mathrm{NaNO}_{2}$. After 5 min incubation at R.T., $30 \mu \mathrm{L}$ of $10 \% \mathrm{AlCl}_{3}$ were added, and after 5 more minutes, $200 \mu \mathrm{L}$ of $1 \mathrm{M} \mathrm{NaOH}$ was added. Finally, the volume was made up to $1 \mathrm{~mL}$ with deionized water and absorbance was measured at $510 \mathrm{~nm}$ using a Beckman spectrophotometer (DU 640). Flavonoid concentration was obtained by comparison with a calibration curve based on different concentrations of quercetin (15 to $300 \mu \mathrm{g} / \mathrm{mL})$, and the total flavonoid content was expressed as mg Quercetin Equivalents $(\mathrm{QE})$.

\subsection{HPLC-MS Analysis}

The chromatographic separation of the two extracts was carried out by means of the Agilent $1100 \mu \mathrm{HPLC}$ equipped with an automatic micro-sampler and a Symmetry C18 column (300 A pore size, $5 \mu \mathrm{m}$ particle size, $1 \mathrm{~mm}$ id $\times 150 \mathrm{~mm}$ ) maintained at $30{ }^{\circ} \mathrm{C}$. The injection volume was $8 \mu \mathrm{L}$. The chromatographic method consisted of the following gradient of $45 \mathrm{~min}$ : 0-5 $\min 8 \% \mathrm{~B}, 5-40 \mathrm{~min} 100 \% \mathrm{~B}, 40-45 \mathrm{~min} 100 \% \mathrm{~B}$, at a flow rate of $30 \mu \mathrm{L} / \mathrm{min}$, where $\mathrm{A}$ is $\mathrm{H}_{2} \mathrm{O}$ containing $1 \%$ FOA and $\mathrm{B}$ is methanol. The detector was set at 220/280 nm. Finally, the HPLC was coupled with the mass spectrometer (HPLC-ESI-MS) to qualitatively evaluate the compounds in the extract.

The instrument used is a mass spectrometer with an electrospray ion source (ESI) and a high capacity ion trap (Agilent 1100 MSD XCT ion trap). All parameters have been established to obtain the best ionization of the components. The analysis was performed in an ion charge mode control with target selected at 100,000 and accumulation time of $300 \mathrm{~ms}$. The operating parameters were, capillary voltage: $3.6 \mathrm{~V}$; nebulizer pressure: 20 psi; drying gas: $10 \mathrm{~L} / \mathrm{min}$; dry temperature: $350{ }^{\circ} \mathrm{C}$; moving averages: 3 , fragmentation width $1 \mathrm{~V}$.

All mass spectra were acquired in full-scan and MS-MS mode, acquiring the most abundant species under each peak. Acquisition was performed on negative and positive ions in the 100-1000 mass range and analyzed using the integrated Agilent Data Analysis software (LC/MSD Trap Software).

\subsection{DPPH Radical Scavenging Activity}

The radical scavenging activity was evaluated by the DPPH method [58].

The DPPH test solution, $1 \mathrm{~mL} /$ sample, was prepared as follows: C. amentacea extract dilutions $(1.25,0.5$ and $0.25 \mathrm{mg} / \mathrm{mL})$ in $250 \mu \mathrm{L}$ of water, $500 \mu \mathrm{L}$ of methanol, $250 \mu \mathrm{L}$ of 0.2 mM DPPH (2,2-diphenyl-1-picrylhydrazyl, Calbiochem ${ }^{\circledR}$, Millipore SpA, Milan, Italy) dissolved in methanol.

In the blank sample, the DPPH solution was substituted with methanol, and a negative (only DPPH solution) and a positive control (ascorbic acid $0.5 \mathrm{mg} / \mathrm{mL}$, final concentration) 
were made as well. All samples were incubated for $30 \mathrm{~min}$ at RT in the dark. Samples were read at $517 \mathrm{~nm}$ using a Beckman spectrophotometer (DU 640).

Due to the natural color of the extracts, a solution containing only the extracts in water:methanol 1:3 without DPPH was made as well, in order to subtract the natural absorbance of the extracts at $517 \mathrm{~nm}$ and correct the antioxidant scavenging values obtained. The procedure was carried out three times in duplicate.

\subsection{Reducing Fe (III) Power Assay}

The ability of $C$. amentacea extracts to reduce iron (III) was determined using the method reported by Sampath Kumar et al. [59]. C. amentacea dilutions (1.25, 0.5 and $0.25 \mathrm{mg} / \mathrm{mL}$ ) of both types of extracts were mixed to $250 \mu \mathrm{L}$ of $200 \mathrm{mM}$ phosphate buffer (pH 6.6) and $250 \mu \mathrm{L}$ of $1 \%$ potassium ferricyanide. The mixture was incubated at $50{ }^{\circ} \mathrm{C}$ for $30 \mathrm{~min}$, and then $250 \mu \mathrm{L}$ of $10 \%(w / v)$ TCA was added. The mixture was then centrifuged at 10,000 rpm for $10 \mathrm{~min} .500 \mu \mathrm{L}$ of the supernatant were mixed with $500 \mu \mathrm{L}$ of distilled water and $100 \mu \mathrm{L}$ of $0.1 \%(w / v) \mathrm{FeCl}_{3}$. After $10 \mathrm{~min}$ the absorbance of the resulting solution was measured at $700 \mathrm{~nm}$ using a Beckman spectrophotometer (DU 640). The procedure was carried out in duplicate.

The negative control was produced by replacing the extracts with water, while in the positive control consisted of $20 \mu \mathrm{g} / \mathrm{mL}$ ascorbic acid. The reducing power was calculated as a percentage of the maximum activity of the positive control $(20 \mu \mathrm{g} / \mathrm{mL}$ ascorbic acid).

\subsection{OH Scavenging Activity}

Hydroxyl radical scavenging activity of the extracts was determined using the Mohr's salt method reported by Pavithra et al. [60]. The reaction mixture contained an aliquot of $100 \mu \mathrm{L}$ of extract (starting concentration $5 \mathrm{mg} / \mathrm{mL}), 100 \mu \mathrm{L}$ of iron-EDTA solution $(0.13 \%$ ferrous ammonium sulphate $0.26 \%$ EDTA), $50 \mu \mathrm{L}$ of $0.018 \%$ EDTA solution, $100 \mu \mathrm{L}$ of DMSO solution ( $0.85 \%$ in $0.1 \mathrm{M}$ phosphate buffer, $\mathrm{pH} 7.4)$ and $50 \mu \mathrm{L}$ of $0.22 \%$ ascorbic acid. After an incubation at $80-90{ }^{\circ} \mathrm{C}$ for $15 \mathrm{~min}$, the reaction was stopped by adding $100 \mu \mathrm{L}$ of ice-cold TCA (17.5\%). Finally, $300 \mu \mathrm{L}$ of Nash reagent (75.0 g of ammonium acetate, $3.0 \mathrm{~mL}$ of glacial acetic acid and $2.0 \mathrm{~mL}$ of acetyl acetone in $1 \mathrm{~L}$ of distilled water) were added and read at $412 \mathrm{~nm}$ in a Beckman spectrophotometer (DU640) after $15 \mathrm{~min}$. The intensity of the yellow color was measured at $412 \mathrm{~nm}$ against a blank reagent made with $300 \mu \mathrm{L}$ of Nash reagent, $100 \mu \mathrm{L}$ of ice-cold TCA $(17.5 \%)$ and $600 \mu \mathrm{L}$ of deionized water. The negative control was done by replacing the extracts with water, while in the positive control sample quercetin was used.

\subsection{NO Scavenging Activity}

NO-scavenging activity was evaluated using the assay reported by $\mathrm{Xu}$ et al. [61]. Various dilution of $C$. amentacea extracts (starting concentration $5 \mathrm{mg} / \mathrm{mL}$ ) in $250 \mu \mathrm{L}$ phosphate buffer $(0.1 \mathrm{M}, \mathrm{pH} 7.4)$ were added to $500 \mu \mathrm{L}$ of $5 \mathrm{mM}$ sodium nitroprusside and $250 \mu \mathrm{L}$ of phosphate buffer ( $\mathrm{pH}$ 7.4). Samples were incubated under the light of a lamp at R.T. for $30 \mathrm{~min}$, to produce NO. Afterwards, an equal volume of Griess reagent ( $1 \%$ sulphanilamide, $0.1 \%$ naphthyl-ethylene-diamine in $5 \% \mathrm{H}_{3} \mathrm{PO}_{4}$ ) was added to the mixture. After incubation at R.T. for $10 \mathrm{~min}$ in the dark, the absorbance was measured at $546 \mathrm{~nm}$ trough a Beckman spectrophotometer. For the calibration curve, $\mathrm{NaNO}_{2}$ scalar dilution were used (1-5-10-50 $\mu \mathrm{M})$.

\subsection{Cell Cultures}

The mouse macrophage cell line RAW 264.7 and the mouse fibroblast L929 cell line were obtained from the American Type Culture Collection (LGC Standards srl, Milan, Italy). Cells were cultured at $37^{\circ} \mathrm{C}$ in a humidified, $5 \% \mathrm{CO}_{2}$ atmosphere in high glucose D-MEM with glutamine (Microtech srl, Naples, Italy), supplemented with 10\% FBS (Microtech) with penicillin/streptomycin as antibiotics. 


\subsection{Cytotoxicity Assessment}

The cytotoxicity of the extracts was evaluated on RAW 264.7 murine macrophages and L929 murine fibroblasts. RAW 264.7 macrophages were seeded at 25,000 cells/well, while the L929 fibroblasts were seeded at 10,000/well in 96-well plates. After one day, the extracts were added to the wells and the plates were incubated for $24 \mathrm{~h}$ at $37^{\circ} \mathrm{C}$. Experiments were performed in quadruplicate, $C$. amentacea extracts were added at 5,10 , 50 and $100 \mu \mathrm{g} / \mathrm{mL}$ final concentrations. Solvents alone were tested too ( $1 \%$ final dilutions). At the end of the incubation time, cell viability was assayed by the MTT test performed as already reported [62].

\subsection{Rescue from $\mathrm{H}_{2} \mathrm{O}_{2}$ Cytotoxicity}

Rescue by $\mathrm{C}$. amentacea extracts from $\mathrm{H}_{2} \mathrm{O}_{2}$ cytotoxicity was evaluated in RAW 264.7 macrophages and L929 fibroblasts. Experiments were performed in quadruplicate on 96well plates, RAW 264.7 macrophages were seeded at 25,000 cells/well, while the L929 fibroblasts were seeded at 10,000/well. After one day, cells were challenged with $\mathrm{H}_{2} \mathrm{O}_{2} 500 \mu \mathrm{M}$ in the presence or absence of various concentrations of extracts (from 1 to $100 \mu \mathrm{g} / \mathrm{mL}$ ), and all the plates were incubated for $24 \mathrm{~h}$ at $37^{\circ} \mathrm{C}$. At the end of the incubation time, cell viability was assayed by MTT test.

\subsection{Scavenging of NO Production in LPS-Treated RAW 264.7 Macrophages}

RAW 264.7 macrophages were seeded at $1 \times 10^{6}$ cells/well in 6-well plates, in duplicate. The day after cells were challenged with bacterial lipopolysaccharide (from $100 \mathrm{ng} / \mathrm{mL}$ to $1 \mu \mathrm{g} / \mathrm{mL}$ ) in the presence or absence of $C$. amentacea extracts (50 and $100 \mu \mathrm{g} / \mathrm{mL}$ ). After $24 \mathrm{~h}$ incubation at $37^{\circ} \mathrm{C}$ the nitrite content of the cell media was quantified by the Griess assay (see above "NO scavenging activity" paragraph), while cells were lysed in $400 \mu \mathrm{L}$ lysis buffer (100 mM DTT, 2\% SDS, 10\% glycerol and $50 \mathrm{mM}$ TRIS-HCl, adjusted to $\mathrm{pH} 6.8$ ). The lysates were heated at $100{ }^{\circ} \mathrm{C}$ for $10 \mathrm{~min}$ and the protein concentration was determined by the Bradford assay [63]. Nitrite production in each sample was then calculated through a standard $\mathrm{NaNO}_{2}$ curve and normalised on the protein content of the wells. The experiments were repeated three times.

\subsection{ROS Intracellular Detection}

Experiments were performed as already described [64]. Briefly, cells were seeded in quadruplicate on 96-well plates. RAW 264.7 macrophages were plated at a density of 25,000 cells/well while L929 cells at a density of 10,000 cells/well and allowed to adhere overnight. Cells were then washed once with HBSS and incubated for $30 \mathrm{~min}$ at $37^{\circ} \mathrm{C}$ with $10 \mu \mathrm{M}$ DCF dye (Life Technologies). After incubation with the dye, cells were washed with HBSS, incubated at $37{ }^{\circ} \mathrm{C}$ for 15 min and then challenged with $200 \mu \mathrm{M} \mathrm{H}_{2} \mathrm{O}_{2}$ for $2 \mathrm{~h}$. The plates were finally read on a plate reader, Fluostar Optima BMG, using 485/520 excitation/emission wavelengths. Data are means \pm S.D. of three independent experiments performed in quadruplicate.

\subsection{Gene Expression Analysis in LPS-Activated RAW 264.7 Macrophages}

RAW 264.7 macrophages were seeded at $1 \times 10^{6}$ cells/well in 6-well plates, in duplicate. The day after cells were challenged with bacterial lipopolysaccharide (from $100 \mathrm{ng} / \mathrm{mL}$ to $500 \mathrm{ng} / \mathrm{mL}$ ) in the presence or absence of $C$. amentacea extracts (50 and $100 \mu \mathrm{g} / \mathrm{mL}$ ) for $8 \mathrm{~h}$. Gene expression of the inflammatory mediators, tumor necrosis factor-alpha (TNF- $\alpha$ a.n. NM_001278601.1), interleukin-1beta (IL-1 $\beta$ a.n. NM_008361.4), interleukin-6 (IL-6, NM_031168.2), inducible NO synthase (iNOS, NM_010927.4) and cyclooxygenase-2 (COX2, a.n. NM_011198.4) normalised on GAPDH housekeeping gene (a.n. NM_001289726.1) was evaluated by qPCR. Cell RNA was extracted using the RNeasyMini Kit (Qiagen, Milan, Italy), according to the manufacturer's instructions. Quality and quantity of RNA was analysed using a NanoDrop spectrophotometer (Nanodrop Technologies, Wilmington, DE, USA). The cDNA was synthesized from $1 \mu \mathrm{g}$ RNA by using iScript cDNA Synthesis Kit 
(Bio-Rad Laboratories, Milan, Italy). Each PCR reaction was performed in $10 \mu \mathrm{L}$ containing: $1 \times$ master mix iQ SYBR Green (Bio-Rad), $0.2 \mu \mathrm{M}$ of each primers and $5 \mathrm{ng}$ of synthesized cDNA. All samples were analysed in triplicate. The following thermal conditions were used: Initial denaturation at $95^{\circ} \mathrm{C}$ for $3 \mathrm{~min}$, followed by 45 cycles with denaturation at 95 ${ }^{\circ} \mathrm{C}$ for $15 \mathrm{~s}$, annealing and elongation at $60{ }^{\circ} \mathrm{C}$ for $60 \mathrm{~s}$. The fluorescence was measured at the end of each elongation step. The values were normalized to GAPDH (reference gene) mRNA expression. All primers (Table 2) were designed using the Beacon Designer 7.0 software (Premier Biosoft International, Palo Alto CA, USA) and obtained from TibMolBiol (Genova, Italy). Data analyses were obtained using the DNA Engine Opticon 3 Real-Time Detection System Software program (3.03 version) and, in order to calculate the relative gene expression compared to an untreated (control) calibrator sample, the comparative threshold Ct method was used [65] within the Gene Expression Analysis for iCycler iQ Real Time Detection System software (Bio-Rad, Milan, Italy).

Table 2. List of primers used in qPCR experiments.

\begin{tabular}{ccccc}
\hline GENE & GenBank (a.n.) & Forward & Reverse & $\begin{array}{c}\text { Size } \\
\text { (bp) }\end{array}$ \\
\hline COX-2 & NM_011198.4 & CCAgCAAAgCCTAgAgCAAC & AgCACAAAACCAggATCAgg & 126 \\
\hline IL-1 $\beta$ & NM_008361.4 & gCAgCACATCAACAAgAg & CAgCAggTTATCATCATCATC & 184 \\
\hline TNF- $\alpha$ & NM_001278601.1 & CCACCATCAAggACTCAA & ATCTTATCCAgCCTCATTCT & 120 \\
\hline IL-6 & NM_031168.2 & ACCTgTCTATACCACTTC & gCATCATCgTTgTTCATA & 117 \\
\hline iNOS & NM_010927.4 & CCgCCgCTCTAATACTTA & TTCATCAAggAATTATACAggAA & 121 \\
\hline GAPDH & NM_001289726.1 & TCTCCCTCACAATTTCCATCCCAg & gggTgCAGCgAACTT TATTgATgg & 99 \\
\hline \multicolumn{7}{c}{ Primer pairs used in gene expression quantification by qPCR analysis in RAW 264.7 murine macrophages. } &
\end{tabular}

\subsection{Statistical Analyses}

Statistical analyses were performed through one-way ANOVA and Tukey's post-test per each extract, in order to assess possible differences among the various concentrations used in each assay (GraphPad Software, Inc., San Diego, CA, USA). $p<0.05$ were considered significant.

Author Contributions: Conceptualization, M.C., G.D.L.F. and S.S.; methodology, S.S., G.D.L.F. and M.C.; investigation, S.S., S.M., M.F., G.D.L.F., V.A., M.C., A.S. and G.D.; data curation S.S.; writing S.S., M.C. and G.D.L.F.; review and editing, S.S., G.D.L.F., M.C. and V.A.; supervision, S.S.; funding acquisition, S.S., M.C., G.D. and V.A. All authors have read and agreed to the published version of the manuscript.

Funding: This work was supported by grants from the University of Genova to S.S. and M.C., and also from the EMBRIC TA programme through the funded project SHE: Seaweeds for Human and Environmental health n. 4995 to V.A.

Conflicts of Interest: The authors declare no conflict of interest.

\section{References}

1. Ferrero-Miliani, L.; Nielsen, O.H.; Andersen, P.S.; Girardin, S.E. Chronic inflammation: Importance of NOD2 and NALP3 in interleukin-1beta generation. Clin. Exp. Immunol. 2007, 147, 227-235. [CrossRef]

2. Sanada, F.; Taniyama, Y.; Muratsu, J.; Otsu, R.; Shimizu, H.; Rakugi, H.; Morishita, R. Source of chronic inflammation in aging. Front. Cardiovasc. Med. 2018, 5, 12. [CrossRef]

3. Nathan, C. Nitric oxide as a secretory product of mammalian cells. FASEB J. 1992, 6, 3051-3064. [CrossRef] [PubMed]

4. Knöferl, M.W.; Diodato, M.D.; Schwacha, M.G.; Cioffi, W.G.; Bland, K.I.; Chaudry, I.H. Cyclooxygenase-2-mediated regulation of Kupffer cell interleukin-6 production following trauma-hemorrhage and subsequent sepsis. Shock 2001, 16, 479-483. [CrossRef] [PubMed]

5. Arango Duque, G.; Descoteaux, A. Macrophage cytokines: Involvement in immunity and infectious diseases. Front. Immunol. 2014, 5, 491. [CrossRef] [PubMed] 
6. Beutler, B.A. The role of tumor necrosis factor in health and disease. J. Rheumatol. Suppl. 1999, 57, 16-21. [PubMed]

7. Ames, B.N.; Shigenaga, M.K.; Hagen, T.M. Oxidants, antioxidants, and the degenerative diseases of aging. Proc. Natl. Acad. Sci. USA 1993, 90, 7915-7922. [CrossRef]

8. Klaunig, J.E.; Xu, Y.; Bachowski, S.; Jiang, J. Free radical induced changes in chemical carcinogenesis. In Free Radical Toxicology; Wallace, K.B., Ed.; Taylor and Francis: Washington, DC, USA, 1997; pp. 375-400.

9. Aruoma, O.I. Nutrition and health aspects, of free radicals and antioxidants. Food Chem. Toxicol. 1994, 32, 671-683. [CrossRef]

10. Kehrer, J.P. Free radicals as mediators of tissue injury and disease. Crit. Rev. Toxicol. 1993, 23, 21-48. [CrossRef]

11. Yan, X.; Nagata, T.; Fan, X. Antioxidative activities in some common seaweed. Plant Foods Hum. Nutr. 1998, 52, $253-262$. [CrossRef]

12. Hirose, Y.; Yoshimi, N.; Suzui, M.; Kawabata, K.; Tanaka, T.; Mori, H. Expression of bcl-2, bax, and bcl-XL proteins in azoxymethane-induced rat colonic adenocarcinomas. Mol. Carcinog. 1997, 19, 25-30. [CrossRef]

13. Tanna, B.; Mishra, A. Metabolites unravel nutraceutical potential of edible seaweeds: An emerging source of functional food. Compr. Rev. Food Sci. Food Saf. 2018, 17, 1613-1624. [CrossRef]

14. Heffernan, N.; Brunton, N.P.; FitzGerald, R.J.; Smyth, T.J. Profiling of the molecular weight and structural isomer abundance of macroalgae-derived phlorotannins. Mar. Drugs 2015, 13, 509-528. [CrossRef] [PubMed]

15. Pinteus, S.; Alves, C.; Monteiro, H.; Araújo, E.; Horta, A.; Pedrosa, R. Asparagopsis armata and Sphaerococcus coronopifolius as a natural source of antimicrobial compounds. World J. Microbiol. Biotechnol. 2015, 31, 445-451. [CrossRef]

16. Smit, A.J. Medicinal and pharmaceutical uses of seaweed natural products: A review. J. Appl. Phycol. 2004, 16, 245-262. [CrossRef]

17. Brito da Matta, C.B.; De Souza, É.T.; De Queiroz, A.C.; De Lira, D.P.; De Araújo, M.V.; Cavalcante-Silva, L.H.A.; De Miranda, G.E.C.; De Araújo-Junior, J.X.; Barbosa-Filho, J.M.; De Oliveiras Santos, B.V.; et al. Antinociceptive and anti-inflammatory activity from algae of the genus Caulerpa. Mar. Drugs. 2011, 9, 307-318. [CrossRef]

18. Alves, C.; Pinteus, S.; Horta, A.; Pedrosa, R. High cytotoxicity and anti-proliferative activity of algae extracts on an in vitro model of human hepatocellular carcinoma. SpringerPlus 2016, 5, 1339. [CrossRef]

19. Al-Amoudi, O.A.; Mutawie, H.H.; Patel, A.V.; Blunden, G. Chemical composition and antioxidant activities of Jeddah corniche algae. Saudi Arabia. Saudi J. Biol. Sci. 2009, 16, 23-29. [CrossRef]

20. Costa, L.S.; Fidelis, G.P.; Cordeiro, S.L.; Oliveira, R.M.; Sabry, D.A.; Câmara, R.B.G.; Nobre, L.T.D.B.; Costa, M.S.S.P.; AlmeidaLima, J.; Farias, E.H.C.; et al. Biological activities of sulfated polysaccharides from tropical seaweeds. Biomed. Pharmacother. 2010, 64, 21-28. [CrossRef]

21. Cox, S.; Abu-Ghannam, N.; Gupta, S. An assessment of the antioxidant and antimicrobial activity of six species of edible Irish seaweeds. Int. Food Res. J. 2010, 17, 205-220.

22. Kang, H.S.; Chung, H.Y.; Kim, J.Y.; Son, B.W.; Jung, H.A.; Choi, J.S. Inhibitory phlorotannins from the edible brown alga Ecklonia stolonifera on total reactive oxygen species (ROS) generation. Arch. Pharmacal Res. 2004, 27, 194-198. [CrossRef]

23. Kindleysides, S.; Quek, S.Y.; Miller, M.R. Inhibition of fish oil oxidation and the radical scavenging activity of New Zealand seaweed extracts. Food Chem. 2012, 133, 1624-1631. [CrossRef]

24. Balboa, E.M.; Conde, E.; Moure, A.; Falqué, E.; Domínguez, H. In vitro antioxidant properties of crude extracts and compounds from brown algae. Food Chem. 2013, 138, 1764-1785. [CrossRef]

25. Pinteus, S.; Silva, J.; Alves, C.; Horta, A.; Fino, N.; Rodrigues, A.I.; Mendes, S.; Pedrosa, R. Cytoprotective effect of seaweeds with high antioxidant activity from the Peniche coast (Portugal). Food Chem. 2017, 218, 591-599. [CrossRef]

26. Cotas, J.; Leandro, A.; Monteiro, P.; Pacheco, D.; Figueirinha, A.; Gonçalves, A.M.M.; da Silva, G.J.; Pereira, L. Seaweed phenolics: From extraction to applications. Mar. Drugs 2020, 18, 384. [CrossRef]

27. Christie, H.; Jørgensen, N.M.; Norderhaug, K.M. Bushy or smooth, high or low; importance of habitat architecture and vertical position for distribution of fauna on kelp. J. Sea Res. 2007, 58, 198-208. [CrossRef]

28. Airoldi, L.; Ballesteros, E.; Buonuomo, R.; Van Belzen, J.; Bouma, T.J.; Cebrian, E.; De Clerk, O.; Engelen, A.H.; Ferrario, F.; Fraschetti, S.; et al. Marine forests at risk: Solutions to halt the loss and promote the recovery of Mediterranean canopy-forming seaweeds. In Proceedings of the 5th Mediterranean Symposium on Marine Vegetation, Portoroz, Slovenia, 27-28 October 2014.

29. Valls, R.; Mesguiche, V.; Piovetti, L.; Prost, M.; Peiffer, G. Meroditerpenes from the brown alga Cystoseira amentacea var. stricta collected off the French mediterranean coast. Phytochemistry 1996, 41, 1367-1371. [CrossRef]

30. Mesguiche, V.; Valls, R.; Piovetti, L.; Banaigs, B. Meroditerpenes from Cystoseira amentacea var. stricta collected off the French mediterranean coasts. Phytochemistry 1997, 45, 1489-1494. [CrossRef]

31. Gaysinski, M.; Ortalo-Magné, A.; Thomas, O.P.; Culioli, G. Extraction, purification, and NMR analysis of terpenes from brown algae. In Methods in Molecular Biology Book Series; Humana Press: Clifton, NJ, USA, 2015; Volume 1308, pp. 207-223. [CrossRef]

32. Bruno de Sousa, C.; Gangadhar, K.N.; Macridachis, J.; Pavao, M.; Morais, T.R.; Campino, L.; Varela, J.; Lago, J.H.G. Cystoseira algae (Fucaceae): Update on their chemical entities and biological activities. Tetrahedron Asymmetry 2017, 28, 1486-1505. [CrossRef]

33. Banaigs, B.; Francisco, C.; Gonzalez, E.; Fenical, W. Diterpenoid metabolites from the marine alga Cystoseira elegans. Tetrahedon 1983, 39, 629-638. [CrossRef]

34. Mhadhebi, L.; Mhadhebi, A.; Robert, J.; Bouraoui, A. Antioxidant, anti-inflammatory and antiproliferative effects of aqueous extracts of three mediterranean seaweeds of the genus Cystoseira. Iran. J. Pharm. Res 2014, 13, 207-220. 
35. Stanoikovic, T.P.; Konic-Ristic, A.; Kljajic, Z.; Grozdanic-Stanisavljevic, N.; Srdic-Rajic, T.; Zdunic, G.; Savikin, K. Antioxidant, antiplatelet and cytotoxic activity of extract of Cystoseira amentacea from the coast of Montenegro (South-east Adriatic Sea). Digest J. Nanomater. Biostruct. 2014, 9, 869-880.

36. Ruberto, G.; Baratta, M.T.; Biondi, D.M.; Amico, V. Antioxidant activity of extracts of the marine algal genus Cystoseira in a micellar model system. J. Appl. Phycol. 2001, 13, 403-407. [CrossRef]

37. Mannino, A.M.; Vaglica, V.; Oddo, E. Seasonal variation in total phenolic content of Dictyopteris polypoides (Dictyotaceae) and Cystoseira amentacea (Sargassaceae) from the Sicilian coast. Flora Mediter. 2014, 24, 39-50. [CrossRef]

38. Kosanic, M.; Rankovic, B.; Stanojkovic, T. Biological potential of marine macroalgae of the genus Cystoseira. Acta Biol. Hung. 2015, 66, 374-384. [CrossRef]

39. Vizetto-Duarte, C.; Custódio, L.; Acosta, G.; Lago, J.H.G.; Morais, T.R.; Bruno de Sousa, C.; Gangadhar, K.N.; Rodrigues, M.J.; Pereira, H.; Lima, R.T.; et al. Can macroalgae provide promising anti-tumoral compounds? A closer look at Cystoseira tamariscifolia as a source for antioxidant and anti-hepatocarcinoma compounds. PeerJ 2016, 4, e1704. [CrossRef]

40. Volf, I.; Ignat, I.; Neamtu, M.; Popa, V.I. Thermal stability, antioxidant activity and photo-oxidation of natural polyphenols. Chem. Pap. 2014, 68, 121-129. [CrossRef]

41. Trifan, A.; Vasincu, A.; Luca, S.V.; Neophytou, C.; Wolfram, E.; Opitz, S.E.W.; Sava, D.; Bucur, L.; Cioroiu, B.I.; Miron, A.; et al. Unravelling the potential of seaweeds from the Black Sea coast of Romania as bioactive compounds sources. Part I: Cystoseira barbata (Stackhouse) C. Agardh. Food Chem. Toxicol. 2019, 134, 110820. [CrossRef]

42. Andrade, P.B.; Barbosa, M.; Matos, R.P.; Lopes, G.; Vinholes, J.; Mouga, T.; Valentao, P. Valuable compounds in macroalgae extracts. Food Chem. 2013, 138, 1819-1828. [CrossRef]

43. Belattmania, Z.; Engelen, A.H.; Pereira, H.; Serrao, E.A.; Barakate, M.; Elatouani, S.; Zrid, R.; Bentiss, F.; Chahboun, N.; Reani, A.; et al. Potential uses of the brown seaweed Cystoseira humilis biomass: 2-Fatty acid composition, antioxidant and antibacterial activities. J. Mater. Environ. Sci. 2016, 7, 2074-2081.

44. Winterbourn, C.C. Toxicity of iron and hydrogen peroxide: The Fenton reaction. Toxicol. Lett. 1995, 82-83, 969-974. [CrossRef]

45. Dar, R.A.; Brahman, P.K.; Khurana, N.; Wagay, J.A.; Lone, Z.A.; Ganaie, M.; Pitre, K.S. Evaluation of antioxidant activity of crocin, podophyllotoxin and kaempferol by chemical, biochemical and electrochemical assays. Arab. J. Chem. 2017, 10, s1119-s1128. [CrossRef]

46. Weidinger, A.; Kozlov, A.V. Biological activities of reactive oxygen and nitrogen species: Oxidative stress versus signal transduction. Biomolecules 2015, 5, 472-484. [CrossRef]

47. Amico, V. Marine brown algae of family of Cystoseiraceae: Chemistry and chemotaxonomy. Phytochemistry 1995, 39, 1257-1279. [CrossRef]

48. Amico, V.; Oriente, G.; Neri, P.; Piattelli, M.; Ruberto, G. Tetraprenyltoluquinols from the brown alga Cystoseira stricta. Phytochemistry 1987, 26, 1715-1718. [CrossRef]

49. Moraes, E.P.; Ruperez, F.J.; Plaza, M.; Herrero, M.; Barbas, C. Metabolomic assessment with CE-MS of the nutraceutical effect of Cystoseira spp extracts in an animal model. Electrophoresis 2011, 32, 2055-2062. [CrossRef]

50. Ben Gara, A.; Ben Abdallah Kolsi, R.; Chaaben, R.; Hammami, N.; Kammoun, M.; Patti, F.P.; El Feki, A.; Fki, L.; Belghith, H.; Belghith, K. Inhibition of key digestive enzymes related to hyperlipidemia and protection of liver-kidney functions by Cystoseira crinita sulphated polysaccharide in high-fat diet-fed rats. Biomed. Pharmacother. 2017, 85, 517-526. [CrossRef]

51. Vizetto-Duarte, C.; Pereira, H.; Bruno de Sousa, C.; Rauter, A.P.; Albericio, F.; Custodio, L.; Barreira, L.; Varela, J. Fatty acid profile of different species of algae of the Cystoseira genus: A nutraceutical perspective. Nat. Prod. Res. 2015, 29, 1264-1270. [CrossRef]

52. Ferreres, F.; Lopes, G.; Gil-Izquierdo, A.; Andrade, P.B.; Sousa, C.; Mouga, T.; Valentao, P. Phlorotannin extracts from fucales characterized by HPLC-DAD-ESI-MSn: Approaches to Hyaluronidase inhibitory capacity and antioxidant properties. Mar. Drugs 2012, 10, 2766-2781. [CrossRef]

53. Nakanishi, M.; Rosenberg, D.W. Multifaceted roles of PGE2 in inflammation and cancer. Semin. Immunopathol. 2013, 35, $123-137$. [CrossRef]

54. Patil, K.R.; Mahajan, U.B.; Unger, B.S.; Goyal, S.N.; Belemkar, S.; Surana, S.J.; Oijha, S.; Patil, C.R. Animal models of inflammation for screening of anti-inflammatory drugs: Implications for the discovery and development of phytophamaceuticals. Int. J. Mol. Sci. 2019, 20, 4367. [CrossRef] [PubMed]

55. Korbecki, J.; Baranowska-Bosiacka, I.; Gutowska, I.; Chlubeck, D. The effect of reactive oxygen species on the synthesis of prostanoids from arachidonic acid. J. Physiol. Pharmacol. 2013, 64, 409-421. [PubMed]

56. Scarfi, S.; Benatti, U.; Pozzolini, M.; Clavarino, E.; Ferraris, C.; Magnone, M.; Valisano, L.; Giovine, M. Ascorbic acid-pretreated quartz enhances cyclo-oxygenase-2 expression in RAW 264.7 murine macrophages. FEBS J. 2007, 274, 60-73. [CrossRef] [PubMed]

57. Biju, J.; Sulaiman, C.T.; Sateesh, G.; Reddy, V.R.K. Total phenolics and flavonoids in selected medicinal plants in Kerala. Int. J. Pharm. Pharm. Sci. 2014, 6, 406-408.

58. Pozzolini, M.; Scarfi, S.; Gallus, L.; Castellano, M.; Vicini, S.; Cortese, K.; Gagliani, M.C.; Bertolino, M.; Costa, G.; Giovine, M. Production, characterization and biocompatibility evaluation of collagen membranes derived from marine sponge Chondrosia reniformis Nardo, 1847. Mar. Drugs 2018, 16, 111. [CrossRef] [PubMed]

59. Sampath Kumar, N.S.; Nazeer, R.A.; Jaiganesh, R. Purification and identification of antioxidant peptides from the skin protein hydrolisate of two marine fishes, horse mackerel (Magalapsis cordyla) and croaker (Otholithes ruber). Amino Acids 2012, 42, 1641-1649. [CrossRef] [PubMed] 
60. Pavithra, K.; Vadivukkarasi, S. Evaluation of free radical scavenging activity of various extracts of leaves from Kedrostis foetidissima (Jacq.) Cogn. Food Sci. Hum. Wellness 2015, 4, 42-46. [CrossRef]

61. Xu, Y.; Zhao, H.; Zhang, M.; Li, C.J.; Lin, X.Z.; Sheng, J.; Shi, W. Variatons of antioxidant properties and NO scavenging abilities during fermentation of Tea. Int. J. Mol. Sci. 2011, 12, 4574-4590. [CrossRef]

62. Pozzolini, M.; Vergani, L.; Ragazzoni, M.; Delpiano, L.; Grasselli, E.; Voci, A.; Giovine, M.; Scarfi, S. Different reactivity of primary fibroblasts and endothelial cells towards crystalline silica: A surface radical matter. Toxicology 2016, 361, 12-23. [CrossRef]

63. Bradford, M.M. A rapid and sensitive method for the quantitation of microgram quantities of protein utilizing the principle of protein-dye binding. Anal. Biochem. 1976, 72, 248-254. [CrossRef]

64. Pozzolini, M.; Millo, E.; Oliveri, C.; Mirata, S.; Salis, A.; Damonte, G.; Arkel, M.; Scarfi, S. Elicited ROS scavenging activity, photoprotective, and wound-healing properties of collagen-derived peptides from the marine sponge Chondrosia reniformis. Mar. Drugs 2018, 16, 465. [CrossRef] [PubMed]

65. Vandesompele, J.; De Preter, K.; Poppe, B.; Van Roy, N.; De Paepe, A.; Speleman, F. Accurate normalization of real-time quantitative RT-PCR data by geometric averaging of multiple internal control genes. Genome Biol. 2002, 3, 0034.1-0034.12. [CrossRef] [PubMed] 